\title{
Components of 21 years (1995-2015) of absolute sea level trends in the Arctic
}

\author{
Carsten Bjerre Ludwigsen, Ole Baltazar Andersen, and Stine Kildegaard Rose \\ DTU Space, Elektrovej 328, 2800 Kgs. Lyngby, Denmark
}

Correspondence: Carsten Bjerre Ludwigsen (caanlu@space.dtu.dk)

Received: 4 September 2020 - Discussion started: 5 November 2020

Revised: 26 November 2021 - Accepted: 1 December 2021 - Published: 21 January 2022

\begin{abstract}
The Arctic Ocean is at the frontier of the fastchanging climate in the northern latitudes, and sea level trends are a bulk measure of ongoing processes related to climate change. Observations of sea level in the Arctic Ocean are nonetheless difficult to validate with independent measurements, and this is globally the region where the sea level trend (SLT) is most uncertain. The aim of this study is to create a satellite-independent reconstruction of Arctic SLT, as it is observed by altimetry and tide gauges (TGs). Previous studies use Gravity Recovery and Climate Experiment (GRACE) observations to estimate the manometric (mass component of) SLT. GRACE estimates, however, are challenged by large mass changes on land, which are difficult to separate from much smaller ocean mass changes. Furthermore, GRACE is not available before 2003, which significantly limits the period and makes the trend more vulnerable to short-term changes. As an alternative approach, this study estimates the climate-change-driven Arctic manometric SLT from the Arctic sea level fingerprints of glaciers, Greenland, Antarctica and glacial isostatic adjustment (GIA) with the addition of the long-term inverse barometer (IB) effect. The halosteric and thermosteric components complete the reconstructed Arctic SLT and are estimated by interpolating 300000 temperature $(T)$ and salinity $(S)$ in situ observations.

The SLT from 1995-2015 is compared to the observed SLT from altimetry and 12 selected tide gauges (TGs) corrected for vertical land movement (VLM). The reconstructed estimate manifests the salinity-driven halosteric component as dominating the spatial SLT pattern with variations between -7 and $10 \mathrm{~mm} \mathrm{yr}^{-1}$. The manometric SLT in comparison is estimated to be $1-2 \mathrm{~mm} \mathrm{yr}^{-1}$ for most of the Arctic Ocean. The reconstructed SLT shows a larger sea level rise
\end{abstract}

in the Beaufort Sea compared to altimetry, an issue that is also identified by previous studies. There is a TG-observed sea level rise in the Siberian Arctic in contrast to the sea level fall from the reconstructed and altimetric estimate.

From 1995-2015 the reconstructed SLT agrees within the $68 \%$ confidence interval with the SLT from observed altimetry in $87 \%$ of the Arctic between $65^{\circ} \mathrm{N}$ and $82^{\circ} \mathrm{N}(R=0.50)$ and with 5 of 12 TG-derived (VLM-corrected) SLT estimates. The residuals are seemingly smaller than results from previous studies using GRACE estimates and modeled $T-S$ data. The spatial correlation of the reconstructed SLT to altimetric SLT during the GRACE period (2003-2015) is $R=$ 0.38 and $R=0.34 / R=0.37$ if GRACE estimates are used instead of the constructed manometric component. Thus, the reconstructed manometric component is suggested as a legitimate alternative to GRACE that can be projected into the past and future.

\section{Introduction}

The Arctic is globally the region with the fastest-changing climate and is warming at twice the rate of the global average (Box et al., 2019). The resulting enhanced deglaciation of land, decline of sea ice cover and ocean freshening have several affects on sea level. Hence, observations of sea level are a measure of multiple ongoing processes but naturally lack information on the source of sea level change. Parallel sea level observations from satellite altimetry and tide gauges of the Arctic Ocean are challenged by a harsh environment, sea ice floes and lack of spatial coverage (Smith et al., 2019). Decomposing the observed long-term sea level change provides 
insight into the regional effects of ongoing climate processes and helps consolidate the observed sea level.

Satellite altimetry has measured the sea level of the Arctic Ocean since 1991, with ESA's European Remote Sensing (ERS)-1 satellite being the first reaching polar latitudes. Laxon et al. (2003) were the first to study Arctic sea level from the ERS-1/2 satellites to produce sea ice thicknesses. Since then many have followed (Peacock and Laxon, 2004; Giles et al., 2012; Prandi et al., 2012; Cheng et al., 2015; Rose et al., 2019), but large variability, in particular in seaice-covered regions, is still present (Armitage et al., 2016; Carret et al., 2017; Rose et al., 2019).

The sea level budget has been resolved on global and basin-wide scales for observations since the begin of the 19th century by using a combination of in situ data, satellite observations and probabilistic analysis (Church and White, 2011a; WCRP, 2018; Dangendorf et al., 2019; Royston et al., 2020; Frederikse et al., 2020), but these studies neglect the polar regions due to large uncertainties and the relative small area of the Arctic Ocean in a global context.

Previous studies have made attempts to reconstruct sea level in the Arctic spatially (Henry et al., 2012; Carret et al., 2017; Raj et al., 2020; Ludwigsen and Andersen, 2020), while Armitage et al. (2016) estimate the mass and steric SLT components as a basin-wide average. All previous studies use different solutions of GRACE to obtain their result. Henry et al. (2012) used CSR-RL04 (Bonin et al., 2012) from 2003-2009, Armitage et al. (2016) used JPL-RL05 (Chambers and Bonin, 2012) from 2003-2014 and Raj et al. (2020) used GSFC mascons (RL05) (Luthcke et al., 2013) from 2003-2018. Carret et al. (2017) and Ludwigsen and Andersen (2020) compared the manometric sea level trend of different GRACE solutions, which revealed discrepancies of 5$10 \mathrm{~mm} \mathrm{yr}^{-1}$ among GRACE trend estimates in large areas of the Arctic. This disagreement has been attributed to different methods to remove contamination from land mass changes that leaks into the ocean signal observed by GRACE (Mu et al., 2020). Hence, the chosen GRACE solution is consequential for the closing of the sea level budget and its ability to validate altimetric observations.

In contrast to the mentioned Arctic sea level budget studies, this study bypasses GRACE-based ocean mass estimates by calculating the sea level fingerprints of contemporary land ice loss, glacial isostatic adjustment (GIA) and atmospheric pressure (inverse barometer, IB), which results in a long-term manometric sea level trend estimate. This approach gives three advantages over GRACE: (i) insights on the different contributions to manometric sea level change; (ii) a longer time series that extends into the pre-GRACE era, which has the advantage that non-secular and interannual ocean dynamic mass effects mainly driven by the Arctic Oscillation (AO) (Henry et al., 2012; Volkov and Landerer, 2013; Peralta-Ferriz et al., 2014; Armitage et al., 2018) are reduced; and (iii) the mentioned problem of leakage from ef- fects caused by the low spatial resolution $(300-500 \mathrm{~km}$; Tapley et al., 2004) is avoided.

Combining the manometric 1995-2015 SLT estimates with satellite-independent steric SLT estimates (Ludwigsen and Andersen, 2020) aims to reconstruct the absolute SLT as it is observed by altimetry. Besides consolidating observed sea level change, the sea level budget decomposition permits analysis of the sources of contemporary long-term Arctic sea level change, which also aids predictions of future change.

\section{Method}

Sea level observations from satellite altimetry are measured relative to a terrestrial reference frame and are referred to as geocentric or absolute sea level (ASL) observations. Tide gauges (TGs) measure the sea level while being grounded to the coast and are affected by vertical deformations of the solid Earth, called vertical land movement (VLM). When VLM is defined with respect to the same reference frame as altimetry and added to TG-measured relative sea level (RSL) the ASL is restored:

$\mathrm{ASL}=\mathrm{RSL}+\mathrm{VLM}$.

Changes in ASL (A $\dot{S} L)$ originate either from changed ocean density (steric, $\dot{\eta}$ ) due to changes in salinity (halosteric) or temperature (thermosteric) or from changes in ocean mass, denoted as manometric sea level change, $\dot{M}$ (Gregory et al., 2019). According to Gregory et al. (2019), manometric sea level change can be referred to as the "nonsteric" sea level change and is assumed indifferent to the commonly used ocean bottom pressure (OBP). In this study, the manometric component is both reconstructed (19952015) and retrieved from GRACE observations (2003-2015).

$\mathrm{AS} \mathrm{S}=\dot{\eta}+\dot{M}$

As already mentioned, the steric sea level change is composed of halosteric $\left(\dot{\eta}_{\mathrm{S}}\right)$ and thermosteric $\left(\dot{\eta}_{\mathrm{T}}\right)$ sea level change:

$\dot{\eta}=\dot{\eta}_{\mathrm{S}}+\dot{\eta}_{\mathrm{T}}$

The manometric component is further divided into contributions from changes in the gravitational field, $G$, that together with a spatially uniform constant, $c$, composes the gravitational sea level fingerprint $(N)$ due to different landto-ocean mass changes, $i$, which in this study originate from either different sources of land ice (Greenland - GRE, Northern Hemisphere glaciers - NH, Antarctica including Southern Hemisphere glaciers $-\mathrm{Ant}+\mathrm{SH}$ ) or GIA. Change in atmospheric pressure (inverse barometer, IB) is added to the sea level fingerprints to create the total manometric sea level change, $\dot{M}$.

$\dot{M}=\sum_{i} \dot{N}_{i}+\mathrm{IB}$, where $\dot{N}_{i}=\dot{G}_{i}+\dot{c}_{i}$ 
By substituting Eqs. (4) and (3) into Eq. (2), we achieve the reconstruction of absolute sea level, $\mathrm{ASL}_{\mathrm{r}}$, that is comparable with the altimetry observed ASL (denoted as $\mathrm{ASL}_{\mathrm{A}}$ ):

$\mathrm{A} \dot{\mathrm{S}} \mathrm{L}_{\mathrm{r}}=\sum_{i}\left(\dot{G}_{i}+\dot{c}_{i}\right)+\mathrm{IB}+\dot{\eta}_{\mathrm{S}}+\dot{\eta}_{\mathrm{T}}$.

VLM is split into the viscoelastic solid Earth deformation caused from past millennial ice (un-)loading, GIA, and the elastic adjustment from contemporary (1995-2015) change in ice loading, VLMe, which, as $G$, is a composite of the elastic response from different origins of land ice $(i)$.

$\mathrm{VLM}=\mathrm{GIA}+\sum \mathrm{VLMe}_{i}$

Possible local VLMs not associated with glacial mass redistribution (i.e., non-glacial land water change, tectonics or oil depletion) are not accounted for since little knowledge on their VLM contribution exists. Frederikse et al. (2019) estimated the non-glacial VLM from GRACE observations to vary between $-0.5 \mathrm{~mm} \mathrm{yr}^{-1}$ in North America and $+0.2 \mathrm{~mm} \mathrm{yr}^{-1}$ in the Barents-Kara Sea region.

Adding VLM (Eq. 6) to TG-measured RSL gives, according to Eq. (1), a third ASL estimate, $\mathrm{ASL}_{\mathrm{TG}}$ :

$\mathrm{ASL}_{\mathrm{TG}}=\mathrm{RS}_{\mathrm{TG}}+\mathrm{GI} \mathrm{A}+\sum \mathrm{VL}^{\mathrm{M}} \mathrm{e}_{i}$.

\section{Data}

This study combines various in situ data (temperature and salinity $(T-S)$ profiles, tide gauges and ocean bottom recorders), satellite altimetry, GRACE observations and model data (ECCOv4r4, VLM and geoid change) to reconstruct the Arctic sea level change. In this section is a description of the different datasets and how they are obtained.

\subsection{Altimetry}

The DTU/TUM Arctic Ocean sea level anomaly (SLA) record (Rose et al., 2019) provides an independent estimate of ASL change $\left(\mathrm{ASL}_{\mathrm{A}}\right)$. The altimetric time series covers the whole altimetric era given as monthly grids from September 1991 to September 2018, covering 65 to $81.5^{\circ} \mathrm{N}$ and $180^{\circ} \mathrm{W}-179.5^{\circ} \mathrm{E}$.

Geophysical corrections such as tides and atmospheric delays are applied to the altimetric sea level estimate. Leads (cracks in the sea ice cover) and open ocean are located and separated according to the different classification of their surfaces. The detection of leads is not flawless, and their sparse distribution in the sea ice cover, as well as the uncertainty of the applied geophysical corrections in the Arctic (Stammer et al., 2014; Ricker et al., 2016), makes the sea level estimates more uncertain in the sea-ice-covered region. The altimetric record includes data from four ESA satellites: ERS-1 (1991-1995), ERS-2 (1995-2003), Envisat (2002-2010) and CryoSat-2 (2010-2018). It combines results of different retrackers as well as conventional and SAR altimetry (Rose et al., 2019). In particular, ERS-1/2 has a relatively low spatial resolution and measurements from leads in sea ice are limited. Observations are particularly sparse and uncertain in sea ice regions from ERS-1 (Rose et al., 2019), which is why the altimetry record used for this study begins in 1995 . The SAR altimeter on CryoSat-2 is designed to measure over the sea ice cover, which increases the observations from leads and decreases the uncertainty (Rose et al., 2019). The applied version of the DTU/TUM altimetry product is not corrected for GIA or atmosphere pressure loading.

\subsection{Tide gauges and vertical land movement}

Observations from tide gauges (TGs) are obtained from the Permanent Service of Sea Level (PSMSL) database (Holgate et al., 2012) given as monthly SLA. TGs with a consistent time series are few and unevenly distributed in the Arctic (Henry et al., 2012; Limkilde Svendsen et al., 2016). Usually, TG-observed RSL is aligned to ASL by utilizing vertical velocities from a nearby Global Navigation Satellite System (GNSS) receiver. However, only few reliable GNSS data at the Arctic coast span the time period of this study (Wöppelmann and Marcos, 2016; Ludwigsen et al., 2020a), and restricting TGs to locations with usable GNSS significantly limits the selection of TGs further. Therefore, an Arctic-wide VLM model with annual VLM rates from 1995-2015 (Ludwigsen et al., 2020a) is used as a substitute for GNSS (Fig. 1). A detailed comparison between vertical rates from the used VLM model and GNSS measurements (from URL6B; Santamaría-Gómez et al., 2017) showed good agreement, in particular along the Norwegian coast (Ludwigsen et al., 2020a).

The region around the Ny-Ålesund TG and Reykjavik TG experiences extraordinary VLM that is caused by substantial deglaciation during the Little Ice Age (LIA) (Svalbard) and low mantle viscosities in Iceland and Greenland. This is not captured in the spatially uniform REF6371 Earth model (Kustowski et al., 2007) used in the VLM model. Therefore, the two sites are corrected with nearby GNSS instead of the VLM model. Large residual trends between the VLM model $\left(-1.4 \mathrm{~mm} \mathrm{yr}^{-1}\right)$ and GNSS $\left(-3.2 \mathrm{~mm} \mathrm{yr}^{-1}\right)$ were also found at Prudhoe Bay. This additional subsidence is likely caused by nearby construction or oil depletion sites. However, the tide gauge is located on a peninsula reaching into the Beaufort Sea $10 \mathrm{~km}$ away from the GNSS location, which is why the VLM model is trusted over the GNSS measurement.

The VLM model is composed from Eq. (6). The GIA component is based on the Caron2018 GIA model (Caron et al., 2018), which includes an uncertainty estimate. Reported discrepancies from other GIA models in central North America and Greenland (Caron et al., 2018; Ludwigsen et al., 2020a) have little affect at the locations of TGs of this study. Annual rates of VLMe are estimated from the 1995-2015 annual change in land ice using the Regional Elastic Rebound Calculator (REAR) (Melini et al., 2014). REAR also pro- 

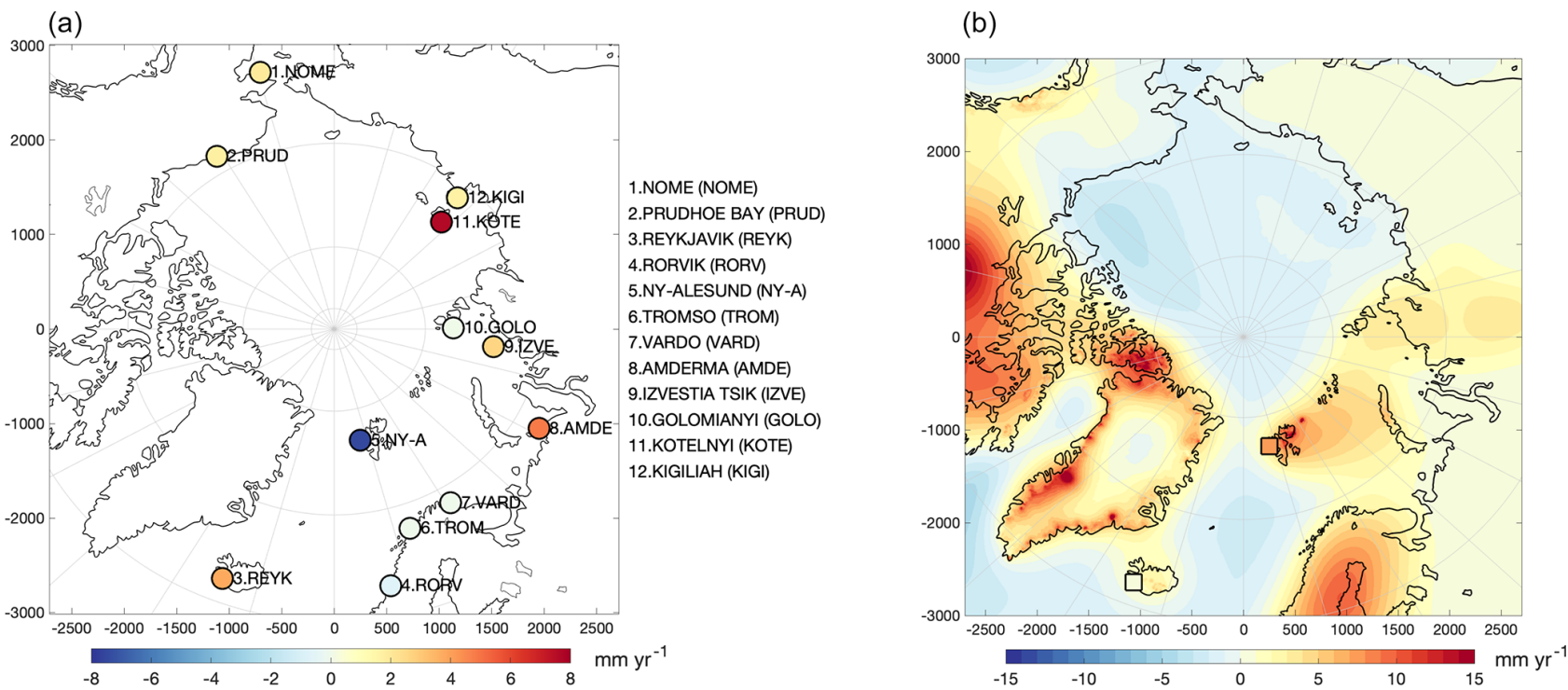

Figure 1. (a) The 1995-2015 RSL trend [ $\mathrm{mm} \mathrm{yr}^{-1}$ ] and location of the selected tide gauges of this study. (b) The 1995-2015 VLM trend $\left[\mathrm{mm} \mathrm{yr}^{-1}\right]$ from the model of Ludwigsen et al. (2020b). The VLM trend from the GNSS sites at Reykjavik and Ny-Ålesund are shown with square color-coded markers.

vides the gravitational response $G$ to land ice change used for estimating the manometric sea level. Uncertainties of the elastic VLM estimates are mainly due to uncertainties of the applied land ice change. An additional $10 \%$ of the VLM signal (after Wang et al., 2012) is added to represent uncertainties associated with the REF6371 Earth model (Kustowski et al., 2007) applied in REAR. The VLM contribution from non-tidal ocean loading (NOL) (van Dam et al., 2012) and rotational feedback (RF) (King et al., 2012) is in total of an order of $\pm 0.3 \mathrm{~mm} \mathrm{yr}^{-1}$ and is included in the VLM contribution from Northern Hemisphere glaciers.

A total of 12 TGs are selected (geographical locations shown in Fig. 1) based on visual inspection of the monthly time series and to ensure that as many regions of the Arctic are represented as possible. The 3-month averaged time series and linear trend of TG-observed sea level $\left(\mathrm{RSL}_{\mathrm{TG}}\right)$ as

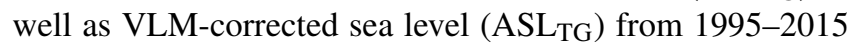
are shown in Fig. 2. The annual VLM model is interpolated onto the TG time series, and the linear trend is determined with the least-squares method using months with available data between 1995 and 2015. In particular, the Alaskan and Siberian TGs have months with no data or unreliable data (flagged by PSMSL). However, there is no evident seasonality in the missing months, and therefore the trend estimates are not significantly affected by a seasonal bias.

Reykjavik $\left(64.2^{\circ} \mathrm{N}\right)$, Nome $\left(64.5^{\circ} \mathrm{N}\right)$ and Rørvik $\left(64.9^{\circ} \mathrm{N}\right)$ are located off the edge of the altimetric data, which only extend to $65^{\circ} \mathrm{N}$, but are nevertheless included to extend the spatial distribution of the TG sites.

From Fig. 2, we see that the RSL trends in the Arctic vary by nearly $\pm 1 \mathrm{~cm} \mathrm{yr}^{-1}$, with Ny-Ålesund on Svalbard having a negative RSL trend of $-7.45 \mathrm{~mm} \mathrm{yr}^{-1}$, while Kostelnyi Island between the Laptev and East Siberian Sea shows a positive trend of $7.67 \mathrm{~mm} \mathrm{yr}^{-1}$. However, after applying the VLM correction, all TGs show a positive ASL trend within a range of $0.38 \mathrm{~mm}^{-1}$ (Prudhoe Bay) and $6.55 \mathrm{~mm}^{-1}$ (Kostelnyi).

\subsection{Steric sea level}

The steric estimate is derived from the DTU steric product (Ludwigsen and Andersen, 2020). The steric heights are calculated from a three-dimensional $T-S$ grid that is interpolated from more than $300000 T-S$ profiles and thus not constrained by any satellite observations. This approach is different to Morison et al. (2012) and Armitage et al. (2016), which use a difference between altimetry and GRACE to estimate steric heights, and Henry et al. (2012), Carret et al. (2017) and Raj et al. (2020), which use model estimates of $T-S$ to calculate the steric component.

$T-S$ profiles from buoys, ice-tethered profiles and ship expeditions in the Arctic Ocean are as shown in Fig. 3: spatially and temporally unevenly distributed and also depending on seasonal accessibility (Behrendt et al., 2018). Especially in the shallow seas along the Siberian coast (Ludwigsen and Andersen, 2020), the data resolution is poor and the areas have the largest uncertainty. In the interior of the Arctic Ocean mostly summer data are available, while in the North Atlantic decent data coverage is reached year-around (Fig. 3). Temperature and salinity data are interpolated by kriging into a monthly $50 \mathrm{~km} \times 50 \mathrm{~km}$ spatial grid on 41 depth levels. If values are more than $3 \sigma$ away from the mean of neighboring grid cells, values from the same month in adjacent years are used. 

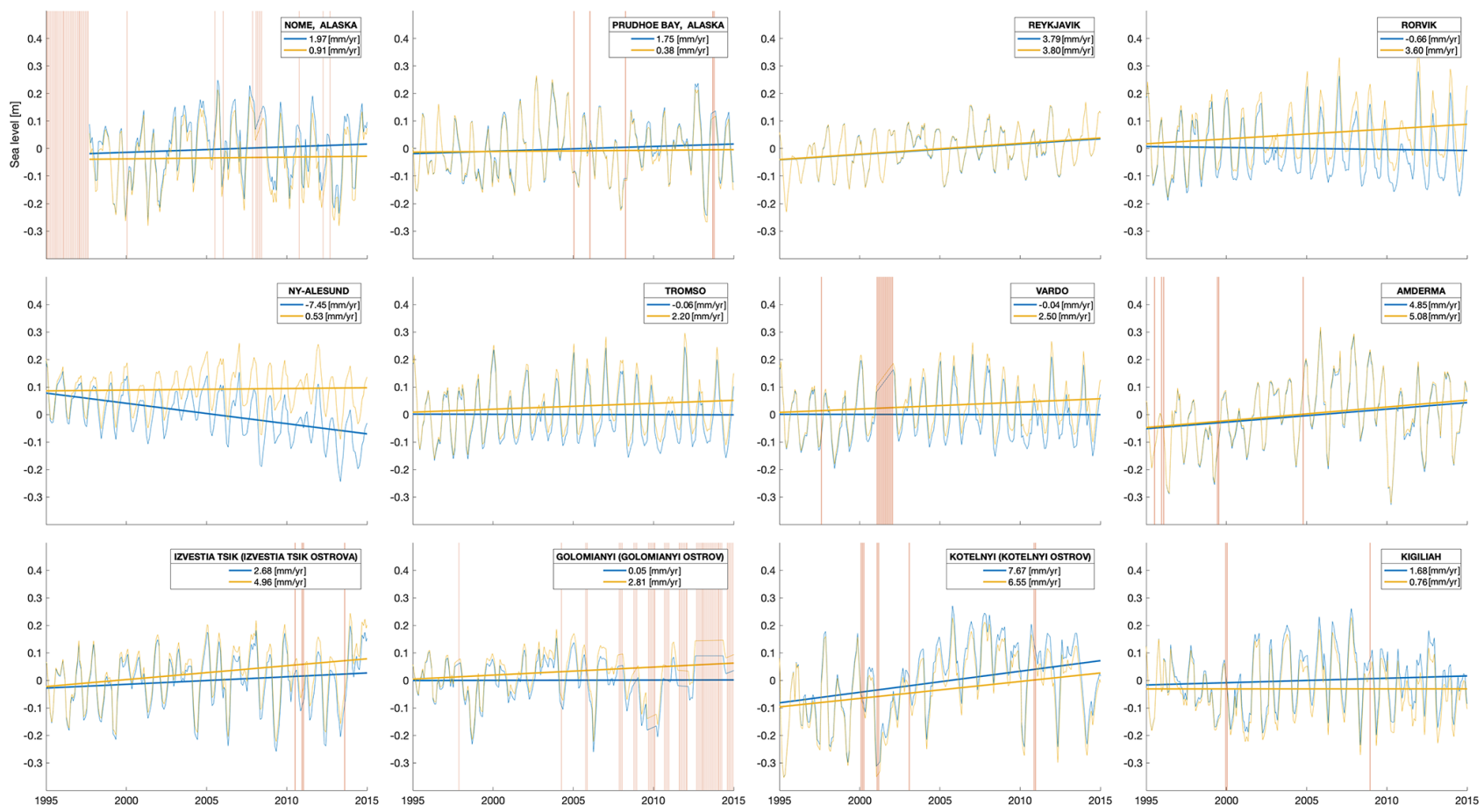

Figure 2. Relative sea level [m] from 1995-2015 registered at the 12 tide gauges from the PSMSL database (Holgate et al., 2012; PSMSL,

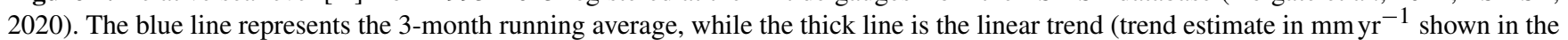
legend). The yellow line represents the absolute sea level and trend, equal to the blue line corrected for VLM with a VLM model (Ludwigsen et al., 2020b) (except Ny-Ålesund and Reykjavik that are corrected with an extrapolated GNSS trend). The vertical lines indicate where observations are missing and the sea level is linearly interpolated from adjacent months.
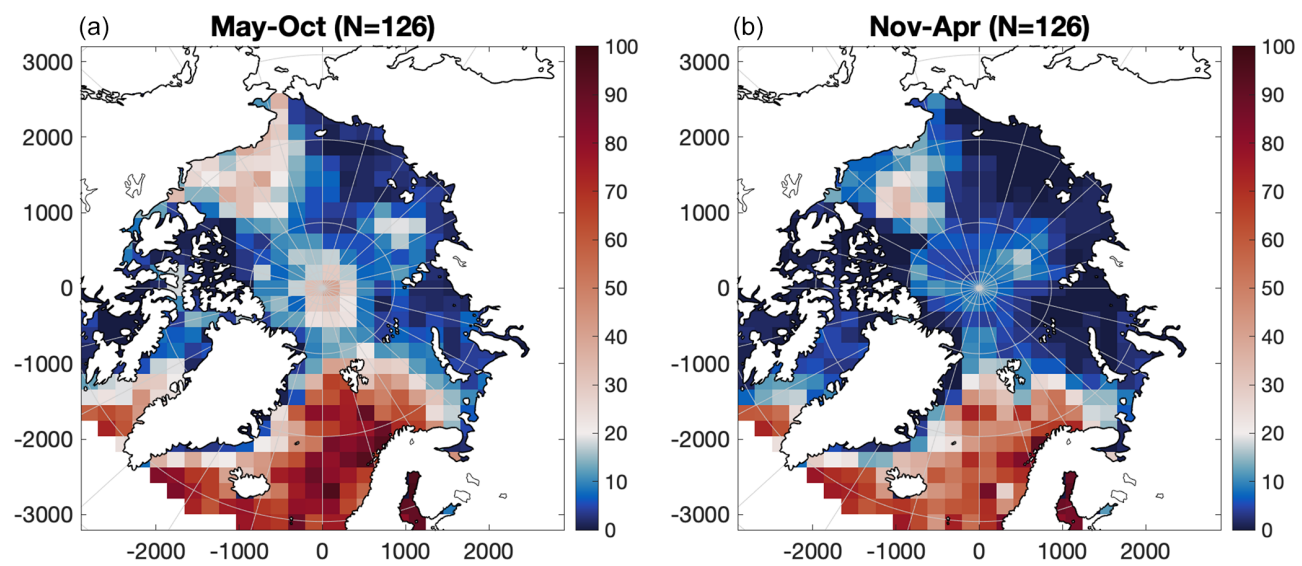

Figure 3. Percentage of months with available $T-S$ data in $200 \mathrm{~km} \times 200 \mathrm{~km}$ grid cells. (a) Summer months (May-October). (b) Winter months (November-April).

Following the notion of Gill and Niller (1973), Stammer (1997), Calafat et al. (2012), and Ludwigsen and Andersen (2020), the change in steric sea level is calculated as the sum of halosteric sea level, $\eta_{\mathrm{S}}$, and thermosteric sea level, $\eta_{\mathrm{T}}$ (Eq. 3). From the depth profiles of the $T-S$ grid, $\eta_{\mathrm{S}}$ and
$\eta_{\mathrm{T}}$ are calculated.

$$
\begin{aligned}
& \eta_{\mathrm{S}}=-\frac{1}{\rho_{0}} \int_{-H}^{0} \beta S^{\prime} \mathrm{d} z \\
& \eta_{\mathrm{T}}=\frac{1}{\rho_{0}} \int_{-H}^{0} \alpha T^{\prime} \mathrm{d} z
\end{aligned}
$$



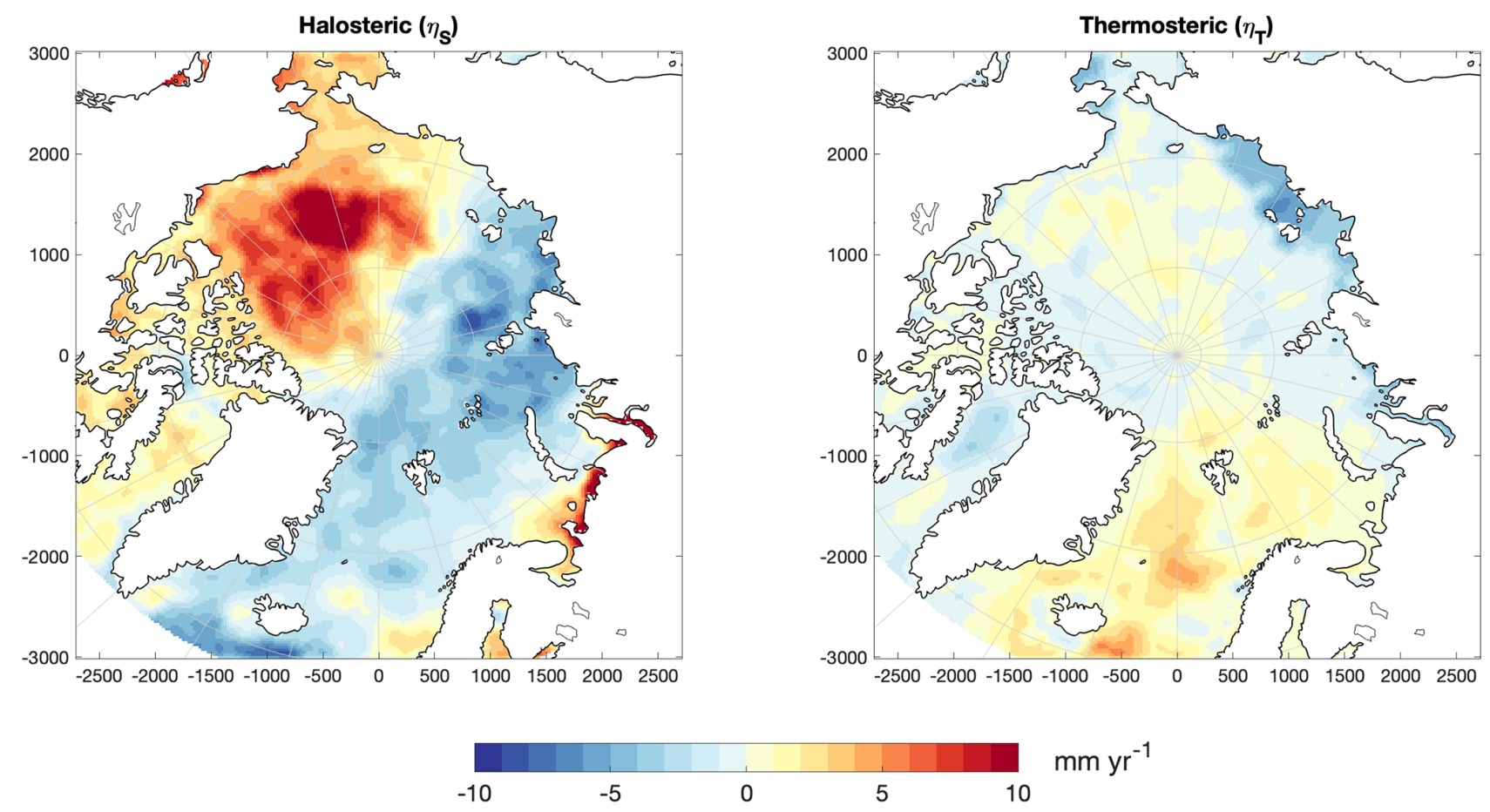

Figure 4. Halosteric and thermosteric sea level trend $\left[\mathrm{mm} \mathrm{yr}^{-1}\right]$ from 1995-2015 derived from the DTU steric sea level product (Ludwigsen and Andersen, 2020).

Here, $H$ denotes the minimum height (maximum depth, $z$ ). The maximum integration depth is as in Ludwigsen and Andersen (2020) at $2000 \mathrm{~m} . S^{\prime}$ and $T^{\prime}$ define salinity and temperature anomalies, with reference values $0^{\circ} \mathrm{C}$ and $35 \mathrm{psu}$, respectively. $\beta$ is the saline contraction coefficient and $\alpha$ is the thermal expansion coefficient. The opposite sign of $\eta_{\mathrm{S}}$ is needed since $\beta$ represents a contraction (opposite to thermal expansion). $\alpha$ and $\beta$ are functions of absolute salinity, conservative temperature and pressure, and they are determined with the freely available TEOS-10 software (Roquet et al., 2015). Sea level trends of $\eta_{\mathrm{S}}$ and $\eta_{\mathrm{T}}$ from 1995-2015 are shown in Fig. 4.

\subsection{Manometric sea level contributions}

Maps of the individual contributions from 1995-2015 to the manometric SLT (from Eq. 4) are shown in Fig. 5. The gravitational sea level fingerprint $(\dot{G})$ of contemporary land ice change (Eq. 4) is computed, similar to the elastic VLM component, by solving the elastic Green's functions with REAR (Melini et al., 2014). The geoid change from GIA is provided by the Caron2018 model (Caron et al., 2018).

The sea level fingerprint of each component (Fig. 5a-d) is retrieved by adding the spatially invariant constant $c$ (global mean sea level change) to the gravitational change. $c$ is equal to the contribution of individual components to global mean sea level (given in brackets in Fig. 5) (Spada, 2017). Follow- ing Spada (2017), $c$ is defined as

$c_{i}=-\frac{M_{i} \rho_{\mathrm{w}}}{A_{\mathrm{O}}}-\left\langle G_{i}-\mathrm{VLM}_{i}\right\rangle$,

where $M_{i}$ is the mass change in the ice model, $A_{\mathrm{O}}$ is the total ocean area, $\rho_{\mathrm{w}}$ is the average density of ocean water and $\langle\ldots\rangle$ denotes the average of the ocean surface. For calculating $c_{i}, G_{i}$ and $\mathrm{VLM}_{i}$ for glaciers, individual glacial mass estimates are combined into a high-resolution model for ice height change (Marzeion et al., 2012; Ludwigsen et al., 2020a). Models are used for mass loss estimates of Greenland (Khan et al., 2016) and Antarctica (Schröder et al., 2019). From 1995 to 2015, the estimated ice loss is $142 \mathrm{Gt} \mathrm{yr}^{-1}$ for Greenland, $206 \mathrm{Gt} \mathrm{yr}^{-1}$ for Northern Hemisphere glaciers, and $105 \mathrm{Gtyr}^{-1}$ for Antarctica and Southern Hemisphere glaciers, consistent with recent studies by Zemp et al. (2019) and Shepherd et al. $(2018,2020)$.

GIA is assumed to be unaffected by contemporary ice changes. This means that the GIA contribution to global mean sea level, $c$, is defined from the right part of Eq. (10), which is estimated to be $0.3 \mathrm{~mm} \mathrm{yr}^{-1}$, consistent with other studies (Peltier, 2009; Spada, 2017). The gravitational sea level change in RF and NOL is less than $0.05 \mathrm{~mm} \mathrm{yr}^{-1}$ and is included in the Northern Hemisphere glacial contribution to $G$.

The manometric SLTs are completed with the loading from atmospheric pressure, IB (Fig. 5e). IB is estimated by the simple relationship derived from the hydrostatic equation 


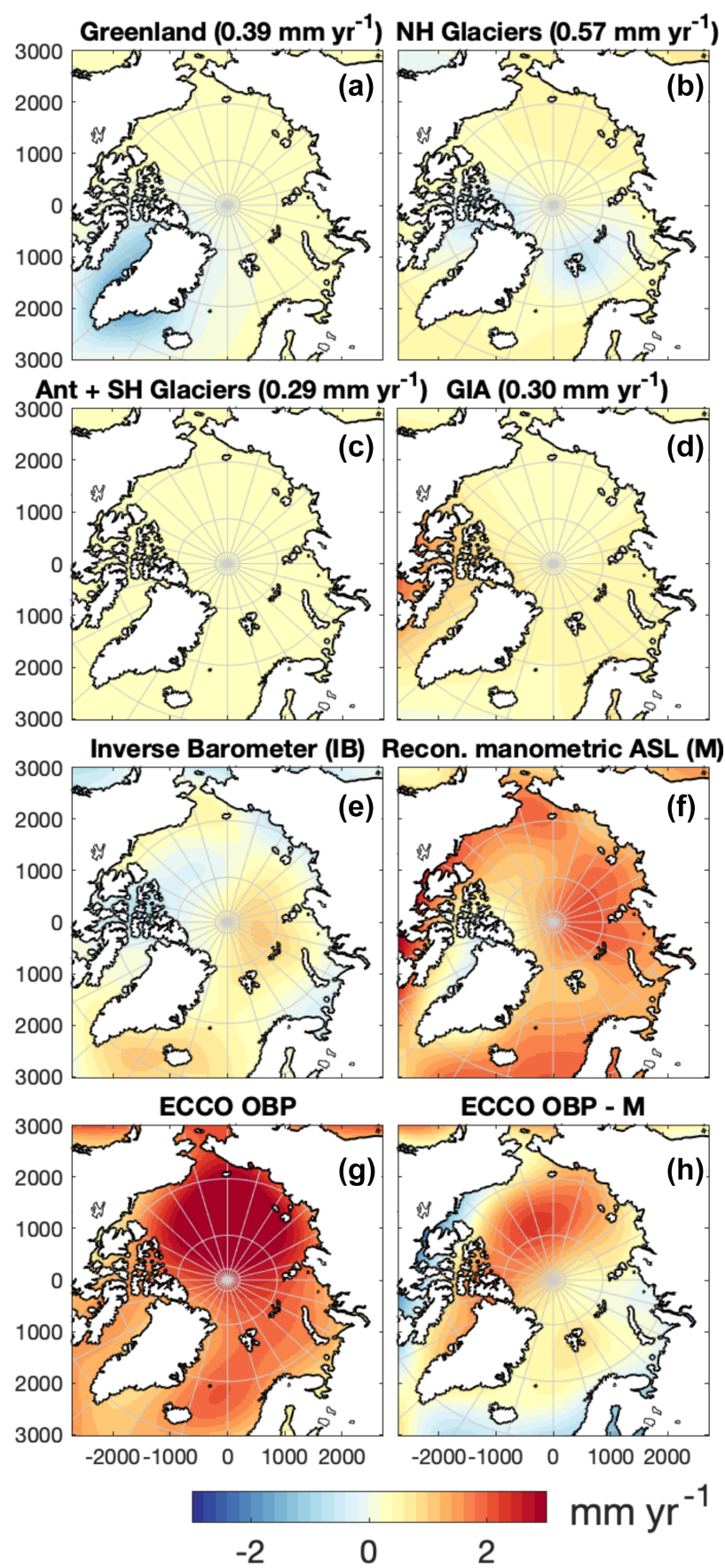

Figure 5. Contributions to the Arctic manometric sea level trend [mm yr ${ }^{-1}$ ] from 1995-2015. (a-d) $\dot{N}$ (Eq. 4) for different sources of land-to-ocean mass changes with the global mean sea level contribution $(\dot{c})$ written in brackets: Greenland (incl. peripheral glaciers) (a), Northern Hemisphere (NH) glaciers (b), Antarctica (Ant) + Southern Hemisphere (SH) glaciers (c), and GIA (d). (e) The estimated inverse barometer trend. (f) The sum of (a-e) and hence the total reconstructed manometric sea level trend. Modeled OBP estimate from ECCOv4r4 (Fukumori et al., 2019) (g). The difference between (g) and (f) is illustrated in panel (h).
(Naeije et al., 2000; Pugh and Woodworth, 2014). Monthly averaged pressure estimates from National Center for Environmental Prediction (NCEP) are used for surface pressure change $\Delta p$ :

$\mathrm{IB}=-9.948\left[\mathrm{~mm} \mathrm{bar}^{-1}\right] \Delta p$.

The total manometric SLTs ( $\dot{M}$, Fig. $5 f)$ are reconstructed as

$\dot{M}=\dot{N}_{\mathrm{NHG}}+\dot{N}_{\mathrm{GRE}}+\dot{N}_{\mathrm{SH}}+\dot{N}_{\mathrm{GIA}}+\mathrm{IB}$.

Figure $5 \mathrm{~g}$ shows the OBP trend from the ECCOv4r4 model (Estimating the Circulation and Climate of the Ocean - ECCO - version 4, release 4) (Forget et al., 2015; Fukumori et al., 2019), which is a model estimate of $\dot{M}$. The ECCO consortium (https://ecco-group.org, last access: 10 July 2021) combines ocean circulation models with observations to estimate different physical parameters of the ocean. The model is, among other aspects, constrained with observations from GRACE, satellite altimetry and in situ $T$ $S$ profiles (Fukumori et al., 2019). The difference between ECCO OBP and $\dot{M}$ is displayed in Fig. $5 \mathrm{~h}$.

Figure 6 shows the reconstructed manometric SLT and ECCO OBP as well as two mascon solutions (release 06) of GRACE (JPL; Watkins et al., 2015; Wiese et al., 2019) and GSFC (Loomis et al., 2019) from 2003-2015 (different scale than Fig. 5) along with the time series for three selected regions.

\section{Results}

The reconstructed SLT from 1995 to $2015\left(\mathrm{AS}_{\mathrm{S}}\right)$ is shown in Fig. $7 \mathrm{i}$ together with the SLT derived from altimetry (Rose et al., 2019). The residual of the reconstructed SLT to altimetry is shown in Fig. 9. In large part, the spatial variability and residual are dominated by the halosteric sea level rise in the Beaufort Sea (10-15 $\left.\mathrm{mm} \mathrm{yr}^{-1}\right)$, halosteric sea level fall in the East Siberian Sea $\left(5-8 \mathrm{~mm} \mathrm{yr}^{-1}\right)$ and thermosteric sea level rise $\left(2-5 \mathrm{~mm} \mathrm{yr}^{-1}\right)$ in the Norwegian Sea, where thermal expansion has a relatively larger impact compared to the near-freezing temperatures in the interior of the Arctic Ocean. A similar pattern is observed by altimetry (Fig. 7ii), although a smaller sea level change in the Beaufort Sea and East Siberian Sea is detected.

Figure $9 \mathrm{~b}$ shows the correlation matrix between $\mathrm{AS} \mathrm{S}_{\mathrm{A} / \mathrm{TG}}$ and $\mathrm{A} \dot{\mathrm{S}} \mathrm{L}_{\mathrm{r}}$. The matrix shows that $\mathrm{A} \dot{\mathrm{S}} \mathrm{L}_{\mathrm{r}}$ and $\mathrm{A} \dot{\mathrm{S}} \mathrm{L}_{\mathrm{A}}$ are largely correlated $(R=0.50)$. There is a large accumulation around $2 \mathrm{~mm} \mathrm{yr}^{-1}$, with slightly higher $\mathrm{AS}_{\mathrm{A}}$ than $\mathrm{A} \dot{\mathrm{S}} \mathrm{L}_{\mathrm{r}}$. This originates from the underestimate of $A \dot{S} L_{r}$ (see figure map in Fig. 9) in the Norwegian Sea. This residual agrees with the ECCO OBP $-\dot{M}$ difference (Fig. $5 \mathrm{~h}$ ) and is thus likely explained by the missing long-term dynamic sea level contribution of $\dot{M}$. From Fig. 9 large residuals in the Beaufort Sea (A $\dot{S} L_{\mathrm{r}}$ higher) and at the Siberian coast $\left(\mathrm{A} \dot{S} \mathrm{~L}_{\mathrm{A} / \mathrm{TG}}\right.$ higher) are also evident. 


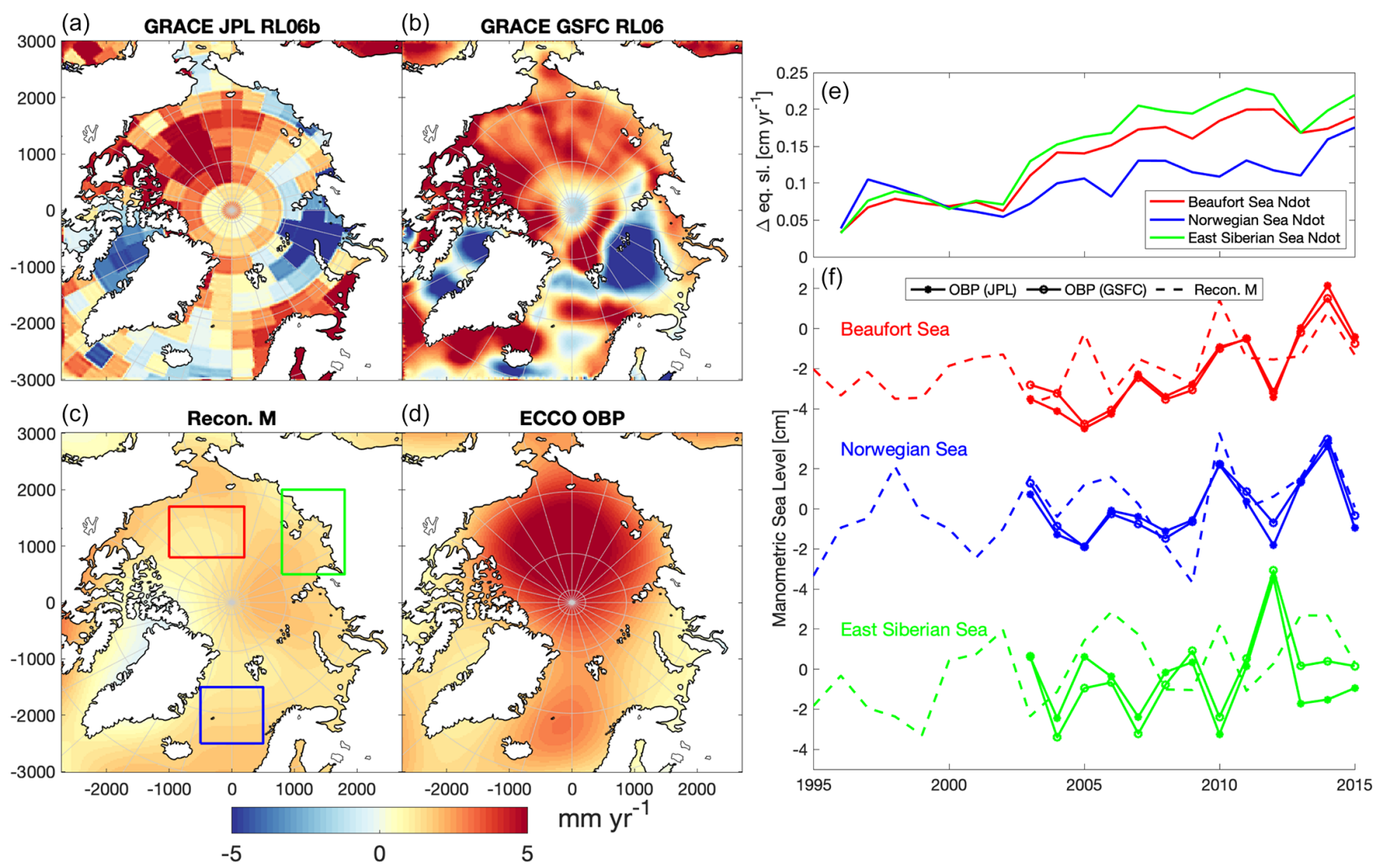

Figure 6. (a-d) Manometric (M) sea level and ocean bottom pressure (OBP) trend estimates [mm yr ${ }^{-1}$ ] from 2003-2015 from two GRACE mascon products $(\mathbf{a}, \mathbf{b})$, reconstructed from the contributions in Fig. 5 (c) and from the ECCO model (d). The year-to-year variation of $N$ (change in geoid + global sea level contribution, Eq. 4) from all sources (land ice + GIA) (in sea level equivalent; $\mathrm{cm} \mathrm{yr}^{-1}$ ) (e). The yearly variation of GRACE OBP estimates and reconstructed manometric sea level in the Beaufort Sea region (red), Norwegian Sea (blue) and East Siberian Sea (green) as indicated by the squares in the map of the reconstructed manometric sea level [cm] (f).

The sea level rise of the Beaufort Sea has been associated with a spin-up of the Beaufort Gyre from 2005 to 2010 that accumulated fresh water (Proshutinsky et al., 2009; Giles et al., 2012; Armitage et al., 2016). The halosteric trend in the Beaufort Sea and thermosteric trend in the Norwegian Sea are in agreement with the steric estimates from 1992-2014 by Carret et al. (2017) and from 2003-2016 by Raj et al. (2020). The steric-driven sea level fall in the East Siberian Sea is not recognized in extent and magnitude by these studies, but is nevertheless in agreement with the observed sea level fall by Armitage et al. (2016), which attributes this pattern to a rapid $10-15 \mathrm{~cm}$ fall in halosteric height in the East Siberian Sea from 2012-2014, resulting in a 2003-2014 ASL trend of around $-5 \mathrm{~mm} \mathrm{yr}^{-1}$. The same 2012-2014 drop in East Siberian Sea is seen in neither $\mathrm{ASL}_{\mathrm{r}}$ nor $\mathrm{ASL}_{\mathrm{A}}$, but is caused by a more general downward trend from 20022013 (Fig. 7iii). Due to an assumed halosteric sea level high from 1998-2002 that coincides with a low in altimetry, the correlation in the East Siberian Sea is poor between $\mathrm{ASL}_{\mathrm{A}}$ and $\mathrm{ASL}_{\mathrm{r}}$ for the whole time series $(R=-0.10)$ but improves when only considering the period from 2003-2015 $(R=0.36)$. The large 2012-2014 steric sea level fall in the
East Siberian Sea shown by Armitage et al. (2016) is also initiated by an apparent GRACE-observed manometric sea level rise seen in Fig. 7iii.

In the two other selected regions (Beaufort and Norwegian Sea) the correlation between $\mathrm{ASL}_{\mathrm{A}}$ and $\mathrm{ASL}_{\mathrm{r}}$ is better for the whole time series (1995-2015) than for the GRACE period (2003-2015). In particular in the Beaufort Sea, the correlation between $\mathrm{ASL}_{\mathrm{A}}$ and $\mathrm{ASL}_{\mathrm{r}}$ is better before 2010. The correlation with altimetry is not significantly approved when ASL is reconstructed using GRACE estimates $\left(\mathrm{ASL}_{\mathrm{r} / \text { grace }}\right.$ for the two regions; Fig. 7iii).

Bottom pressure recorders (BPRs) deployed by the Woods Hole Oceanographic Institution in the Beaufort Sea used to validate GRACE in the Arctic by Peralta-Ferriz and Morison (2010) and Peralta-Ferriz et al. (2014) provide an independent estimate of the manometric sea level change. Because of sensor drift and small changes in location, the BPRs are not usable for detection of trends over longer time periods (Proshutinsky et al., 2019) and therefore not comparable with the manometric sea level reconstruction from Fig. 5. Instead, the mean seasonal cycle of BPR is compared to manometric sea level from GRACE and altimetry $\left(\mathrm{ASL}_{\mathrm{A}}\right)$ minus steric 

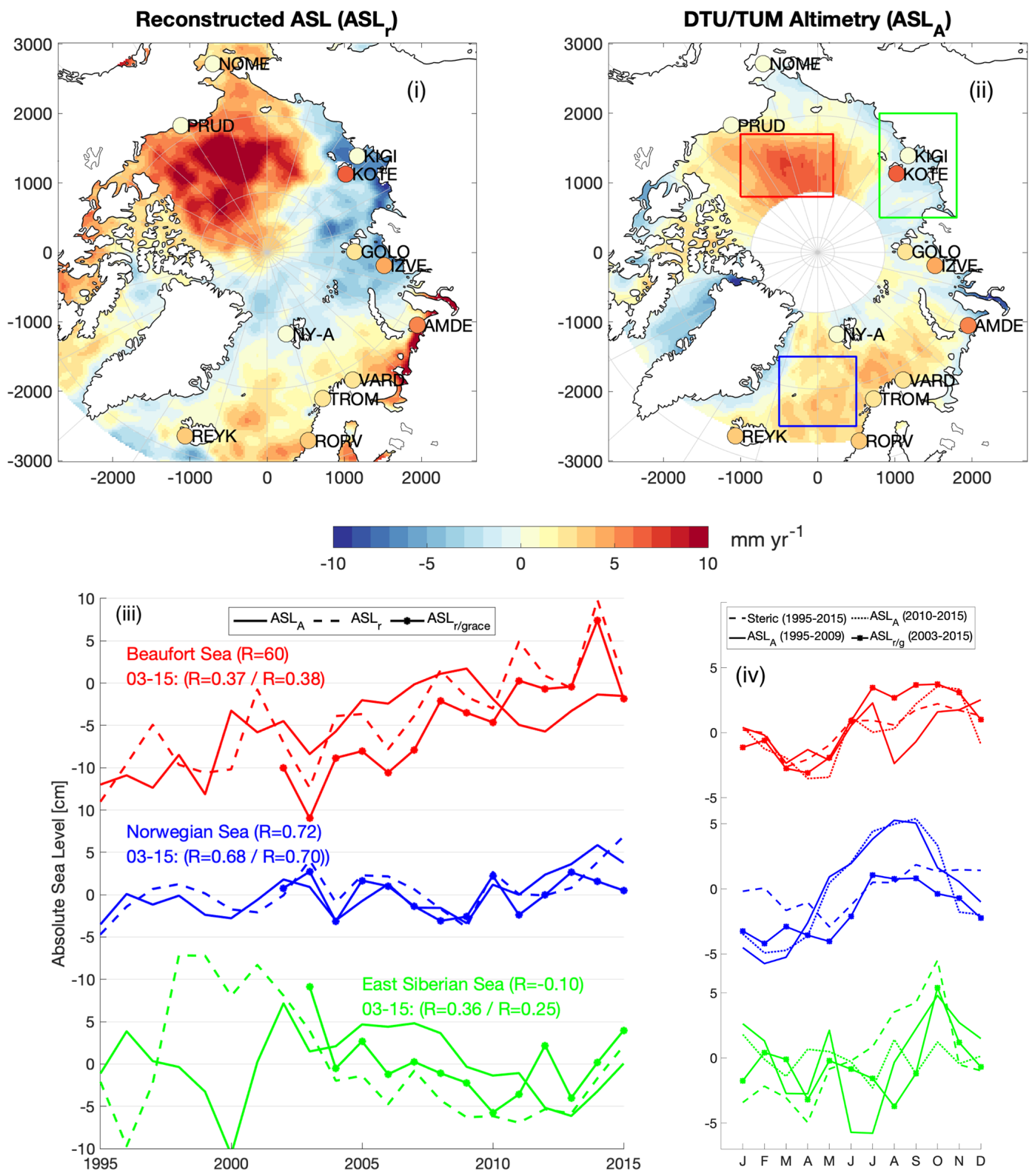

Figure 7. Absolute sea level trend of the reconstructed product ( $\mathrm{AS}_{\mathrm{S}}$ ) (i) and from DTU/TUM altimetry (ASL $\dot{\mathrm{A}}_{\mathrm{A}}$ ) (ii) from 1995 to 2015 $\left[\mathrm{mm} \mathrm{yr}^{-1}\right]$. In both maps the sea level trend of the 12 VLM-corrected tide gauges (ASL $\dot{T G}_{\mathrm{TG}}$ ) is shown with circles. (iii) The time series of $\mathrm{ASL}_{\mathrm{A}}, \mathrm{ASL}_{\mathrm{r}}$ and $\mathrm{ASL}_{\mathrm{r} / \text { grace }}$ (ASL reconstructed with GRACE - mean of the two GRACE estimates used in this study) for three selected regions: Beaufort Sea (red), Norwegian Sea (blue) and East Siberian Sea (green) (areas marked in the DTU/TUM altimetry map). The top $R$ coefficient for each region shows the correlation between $\mathrm{ASL}_{\mathrm{A}}$ and $\mathrm{ASL}_{\mathrm{r}}$, and beneath the $R$ coefficient is shown between ASL

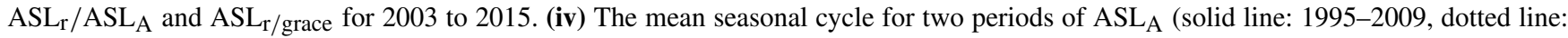
2010-2015), $\mathrm{ASL}_{\mathrm{r} / \mathrm{grace}}\left(\mathrm{ASL}_{\mathrm{r} / \mathrm{g}}\right.$ ) and steric sea level (steric) for the same three regions as in (iii).

in the Beaufort Sea (Fig. 8). It shows that the bottom pressure variations of the BPR correlate better with an altimetry minus steric estimate (inverted from Eq. 2) $(R=0.77)$ compared to the GRACE estimate of seasonal manometric sea level change $(R=0.49)$.

\subsection{Comparing observed and reconstructed manometric sea level change}

The reconstructed manometric sea level trend ( $\dot{M}$, Fig. 5f) varies between 0 and $2 \mathrm{mmyr}^{-1}$, with small spatial variability. The reconstructed manometric contribution is generally much smaller than the estimates from GSFC mascons (RL05) (Luthcke et al., 2013) used by Raj et al. (2020) and CSR 


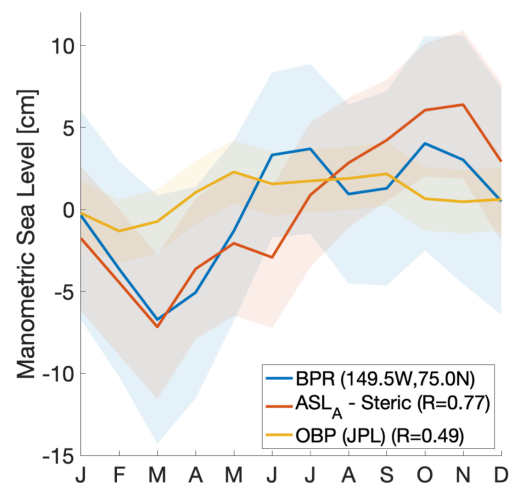

Figure 8. Mean seasonal cycle of manometric sea level from the Beaufort Sea bottom pressure recorder from the Beaufort Gyre Exploration Project, mooring A $\left(149.5^{\circ} \mathrm{W}, 75.0^{\circ} \mathrm{N}\right)$ (blue), DTU al-

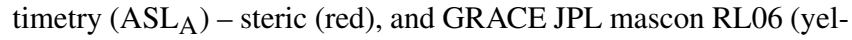
low). Shaded areas indicate 1 standard deviation. Values from altimetry, steric and GRACE are averages from $50 \mathrm{~km}$ around the BPR mooring location. Correlations $(R)$ with BPR are given for GRACE and altimetry minus steric.

RL05 (Save et al., 2016) preferred in Carret et al. (2017). The two RL06 solutions shown in Fig. 6 are more consistent than the RL05 solutions shown in Ludwigsen and Andersen (2020) but still show significant differences. The trends disagree in particular along the eastern Arctic coastlines and the Beaufort Gyre. This is also where the largest residuals between the reconstructed SLT and altimetry are observed (Fig. 9); hence, no obvious manometric SLT is derived from GRACE that is able to explain the residuals between $A \dot{S} L_{A}$ and $\mathrm{A} \dot{\mathrm{S}} \mathrm{L}_{\mathrm{r}}$.

The annual manometric sea level change in two GRACE solutions and the reconstructed estimate for three selected regions in the Arctic Ocean (shown in the bottom right panel of Fig. 6) show temporal similarities in the Beaufort and Norwegian Sea, while a large manometric sea level peak in both GRACE estimates in 2012 in the East Siberian Sea is not explained by the manometric reconstruction. Also, opposite manometric sea level signals are evident, in particular in 2005-2006, in all regions. The annual cycle of the reconstructed manometric sea level is dominated by the inverse barometer effect, while the fluctuations in geoid $(N)$ are an order of magnitude smaller (top right panel of Fig. 6) than the total reconstructed manometric signal. However, the trend estimate $(\dot{N})$ is significantly larger than the IB trend at most locations (Fig. 5).

Figure $5 \mathrm{~g}$ shows that ECCO has larger manometric sea level rise in the interior of the Arctic Ocean, while the coastal zones, except eastern Siberia, are slightly lower than $\dot{M}$. The ECCO model includes a dynamic sea level change associated with wind forcing and ocean currents (Forget et al., 2015). Those dynamic changes are not part of $\dot{M}$ and are probably the main reason for the difference between ECCO OBP and $\dot{M}$ seen in Fig. 5 h. The dynamic mass variations largely follow the temporal variations of the AO (PeraltaFerriz et al., 2014; Armitage et al., 2018). To some extent, the coastal and non-coastal Arctic dipole from Peralta-Ferriz et al. (2014) is recognized in Fig. 5h, but over the extent of the time series of this study, the effect of the AO is assumed to be less significant than the pattern in Peralta-Ferriz et al. (2014), which relies on only 7 years of data. A dynamic mass contribution will also be more significant in the trend of the GRACE estimates that only spans 13 years. A significant manometric sea level rise in the interior of the Arctic Ocean is also recognized by the GRACE estimates in Fig. 6. This is also where GRACE has reached the best correlation with in situ bottom pressure recorders (Peralta-Ferriz et al., 2014), probably because (false) land leakage corrections will be less relevant in the interior of the Arctic Ocean. Since the altimetry record is limited to $81.5^{\circ} \mathrm{N}$, there is no validation of the performance of the reconstructed SLT estimate north of $81.5^{\circ} \mathrm{N}$, but from Fig. 9 we see that the reconstructed SLT is lower than altimetry in most of the visible interior of the Arctic Ocean. The high latitudes of the Beaufort Sea are the exception, where the steric contribution itself is enough to explain the altimetry-observed SLT, and adding a significant manometric sea level rise would increases the residual to altimetry.

Figure 5a-c show that the contributions from contemporary ice loading have a (compared to steric) small contribution to spatial sea level variability, but the sea level fingerprints (Mitrovica et al., 2011) from deglaciation of Greenland and glaciers, however, are still clearly visible with a sea level fall of 0.5 to $1 \mathrm{~mm} \mathrm{yr}^{-1}$. This seems to be qualitatively in agreement with regional sea level fingerprint studies of Bamber and Riva (2010), Spada (2017), and Frederikse et al. (2017). In total, the three figures sum to a sea level rise of around $1 \mathrm{~mm} \mathrm{yr}^{-1}$ in most of the Arctic, except in areas close to land deglaciation (like Greenland and Svalbard). From the top right panel of Fig. 6, it is seen that the sea level contribution from ice changes is accelerating and is almost $0.2 \mathrm{~mm} \mathrm{yr}^{-1}$ by the end of this period. From the comparison with GRACE (Fig. 6) we see that GRACE has a more significant sea level fall in coastal regions with land deglaciation. It is likely that the GRACE estimates are affected by leakage from land mass that is falsely interpreted as an manometric sea level change.

\subsection{Comparing reconstructed absolute sea level with altimetry}

For $87 \%$ of the area of the Arctic between 65 and $82^{\circ} \mathrm{N}$ the reconstructed sea level pattern $\left(A \dot{S} L_{r}\right)$ is in agreement

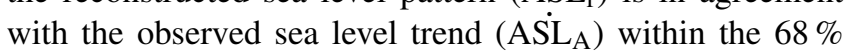
confidence interval (Fig. 9). The main difference between $\mathrm{AS}_{\mathrm{S}}$ and $\mathrm{AS}_{\mathrm{A}}$ is the mentioned larger sea level rise (residual of $+5-10 \mathrm{~mm} \mathrm{yr}^{-1}$ ) in the Beaufort Sea and sea level fall (residual of - 2-5 $\mathrm{mm} \mathrm{yr}^{-1}$ ) in the East Siberian Sea of $A \dot{S} L_{r}$. In the Norwegian Sea the residuals are of the order of 
$\pm 1.5 \mathrm{~mm} \mathrm{yr}^{-1}$, which, because of the low uncertainty in the area, falls outside the $68 \%$ confidence interval in large areas.

The spatial correlation coefficient $(R)$ between $A \dot{S} L_{r}$ and $\mathrm{A} \dot{\mathrm{S}} \mathrm{L}_{\mathrm{A}}$ is 0.50 ( $R=0.23$ without the halosteric contribution) and $R=0.53$ when using the ECCO OBP estimate instead of the reconstructed manometric sea level from 1995-2015. The correlation coefficient falls to $R=0.38$ when limiting the period to 2003-2015. The correlation coefficients reached by Ludwigsen and Andersen (2020) use different release05 GRACE mascons from 2003-2015 ( $\mathrm{R}=0.19-0.40)$ combined with the same steric and an altimetric dataset. When the SLT is reconstructed with release-06 GRACE mascons (A $\dot{\mathrm{S}} \mathrm{L}_{\mathrm{r} / \text { grace }}$ ) the correlation is $R=0.37$ for GSFC and $R=$ 0.34 for JPL and thereby slightly lower than with the reconstructed manometric contribution. This reflects the fact that trend estimates are naturally more sensitive over shorter time series, in particular when the sea level is as dynamic as in the Arctic Ocean.

Before the era of SAR altimetry (pre CryoSat-2, launched in October 2010), the ability to separate the leads and the sea ice was more difficult due to the larger footprint of conventional satellites. Therefore, in areas with dense sea ice cover (like the Beaufort Sea), more altimetric observations exist during the sea level high of the autumn and fewer during winter-spring when sea level is lower (e.g., Armitage et al., 2016). The sampling of the seasonal signal (Fig. 7iv) can create a seasonal bias, which was more pronounced before the CryoSat-2 era because of the lower resolution in the pre-SAR era. This bias can contribute to a flattening of the trend in the Beaufort Sea as seen from the time series in Fig. 7iii. In Fig. $7 \mathrm{i}$ and ii $A \dot{S} \mathrm{~L}_{\mathrm{A}}$ shows a lower trend in the Beaufort Sea than $A \dot{S} L_{r}$, mainly caused by an apparent sea level decline from 2010-2015. Studies of altimetrybased sea level in the Beaufort Sea from Giles et al. (2012) and Armitage et al. (2016) indicate a similar flattening of the sea level anomaly around 2009-2010. The change in sea level trend is attributed to a shift in the cyclonic regime of the Beaufort Gyre in 2010-2011 (Proshutinsky et al., 2015), which released significant amounts of fresh water (Armitage et al., 2016). However, the significant change in the Beaufort Sea coincides with the transition from Envisat to CryoSat-2, and an inter-satellite bias in DTU/TUM altimetry cannot be excluded, thereby contributing to the poor correlation after 2009.

Ludwigsen and Andersen (2020) showed better agreement with the SLT of Armitage et al. (2016) in the Beaufort Sea than the DTU/TUM estimate in the present study using the same steric product and different GRACE estimates. The residuals between $A \dot{S} L_{r}$ and $A \dot{S} L_{A}$ (of this study), however, are seemingly smaller than the results from Raj et al. (2020), who found region-averaged residuals in the Beaufort Sea of $+10 \mathrm{~mm} \mathrm{yr}^{-1}$ from 2003-2009 and $+3.6 \mathrm{~mm} \mathrm{yr}^{-1}$ from 2010-2016 between GSFC GRACE mascons together with a steric model estimate and the same DTU/TUM altimetry product. Carret et al. (2017) also found that the sea level change from altimetry had less spatial variability than the combination of mass and steric from both 1992-2014 and 2003-2010.

The mean seasonal cycle of the Beaufort Sea (panel iv of Fig. 7) shows how a summer and wintertime peak of $A_{S L}$ (in January and June) is visible before 2010 but almost disappears in the CryoSat-2 era. The double peak is also found by Armitage et al. (2016) from 2003 to 2014 but is not nearly as large because of the relatively larger CryoSat-2 weight. Since the manometric components are yearly averaged, only the seasonal variations of the steric component of $\mathrm{ASL}_{\mathrm{r}}$ are shown. From the figure, it is evident that the steric signal dominates the seasonal variation in the Beaufort Sea. A significant residual between steric sea level and $\mathrm{ASL}_{\mathrm{A}}$ indicates a dominant manometric signal $i$ the North Atlantic, in alignment with the results of Carret et al. (2017), who found that the variability in the North Atlantic (GNB sector) is predominantly non-steric.

$\mathrm{ASL}_{\mathrm{A}}$ (Fig. 7) shows a sea level rise in the Norwegian Sea that extends until it reaches the sea ice boundary, which (intentionally) coincides with the average SAR boundary of CryoSat-2. From altimetry it is unclear if this signal is a real physical signal or due to a bias when different altimetric observations (different satellites and SAR/conventional), sea ice and open-ocean regions are aligned (no sea state bias correction in the SAR areas) in the DTU/TUM altimetry product or a known error in the SAR-based DTU18MSS (Andersen et al., 2018) that is used as a reference in the altimetry data. $\mathrm{A} \dot{\mathrm{S}} \mathrm{L}_{\mathrm{r}}$ shows a similar SLT pattern in the Norwegian Sea from a combination of the thermosteric change (warmer ocean) (Fig. 4) and a sea level fall from a gravitational weakening of Greenland (Fig. 5a). The boundary between sea ice and open ocean, however, is less significant in $\mathrm{AS}_{\mathrm{S}}$, and a spatial bias in altimetry therefore cannot be excluded. A thermosteric sea level rise that is countered by a halosteric sea level fall in the Norwegian Sea is also reported by the other studies (Henry et al., 2012; Carret et al., 2017; Raj et al., 2020). The residuals in the present study, however, are qualitatively smaller than the results of the mentioned studies, although they use different subsets of periods, and for the case of Raj et al. (2020) only basin-wide averages are given.

\subsection{Comparing ASL trends in coastal regions}

TGs are only able to observe coastal sea level change, which is often disturbed by the local environment that might be unknown (e.g., small river outflow, local construction, packing of sea ice); this affects both sea level measurements from TGs and altimetry.

In Fig. 10 and Table 1, the contributions to $A \dot{S} L_{r}$ are quantified at the location of each of the 12 TGs by taking the mean trend of a radius of $50 \mathrm{~km}$ ( $5 \mathrm{~km}$ for GIA and elastic VLM). This radius ensures that Rørvik, Nome and Reykjavik overlap the altimetric data, but the fewer data points might cause the altimetry estimates at these TGs to be more variable. The 

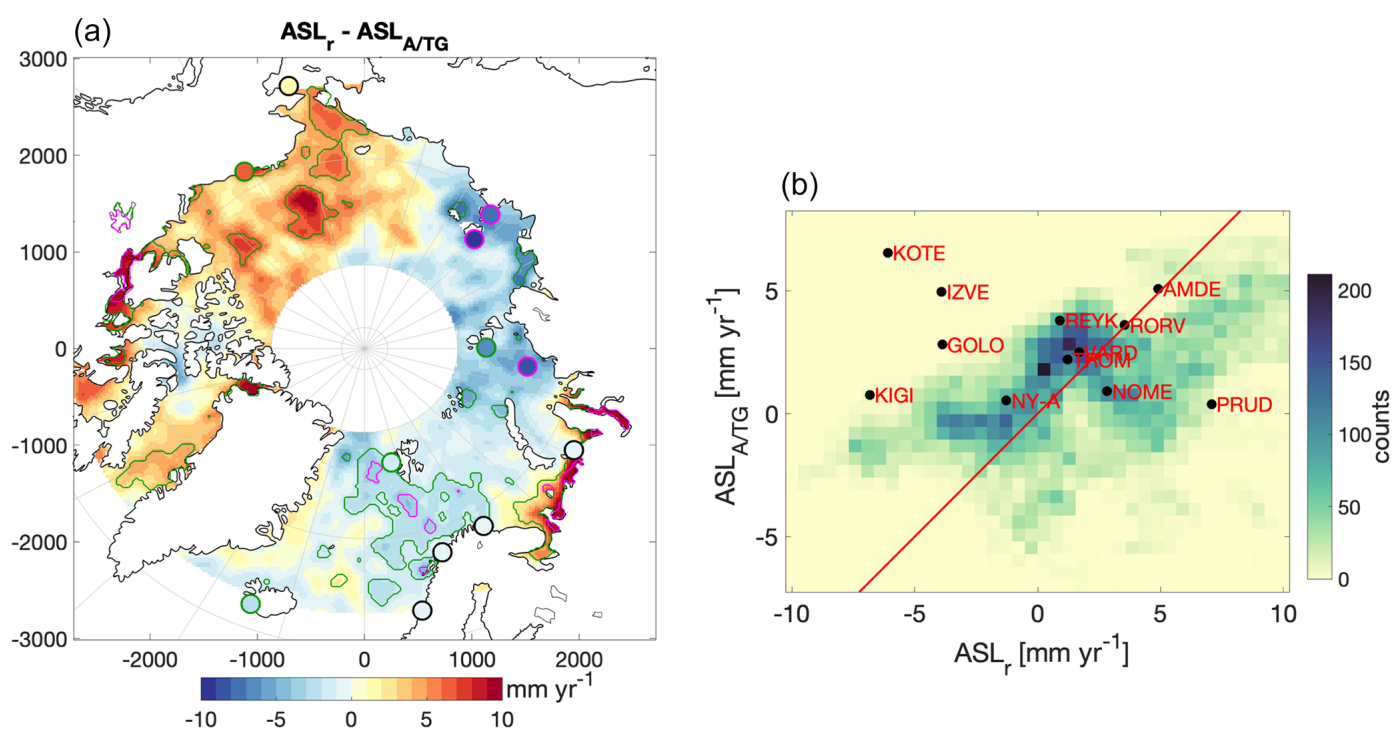

Figure 9. (a) The difference between $\mathrm{A} \dot{S} \mathrm{~L}_{\mathrm{r}}$ and $\mathrm{A} \dot{\mathrm{S}} \mathrm{L}_{\mathrm{A} / \mathrm{TG}}$. The green contour shows the areas or tide gauges (green edge) where the absolute difference is larger than 1 standard error (68\% confidence interval) but less than 2 standard errors (95\% confidence interval) (combined error from Fig. 11). The magenta areas or tide gauges (magenta edge) are where the absolute difference is larger than 2 standard errors. (b) A correlation matrix between $\mathrm{AS}_{\mathrm{r}}$ and $\mathrm{A} \dot{\mathrm{S}} \mathrm{L}_{\mathrm{A} / \mathrm{TG}}$. The color indicates the number of data grid cells falling into a bin size of $0.5 \mathrm{~mm}^{-1}$. A total of $96 \%$ of the grid cells with data are covered within the bounds of the matrix $\left(N_{\text {total }}=18150\right)$. The red line is where $\mathrm{AS} \mathrm{L}_{\mathrm{r}}$ is equal to $\mathrm{AS} L_{\mathrm{A} / \mathrm{TG}}$.

Table 1. The 1995-2015 sea level trends $\left[\mathrm{mm} \mathrm{yr}^{-1}\right.$ ] at the 12 tide gauge locations. The trends (least-squares) are generally based on a annual mean value of a $50 \mathrm{~km}$ radius around the tide gauge. For VLM a $5 \mathrm{~km}$ radius is used, except for Ny-Ålesund and Reykjavik where VLM is based on GNSS measurements. The columns in bold indicate the three estimates of absolute sea level (A $\dot{S} L_{T G}, A \dot{S} L_{r}$ and $\left.A \dot{S} L_{A}\right)$. Errors indicate the 1 standard error equivalent to the $68 \%$ confidence level.

\begin{tabular}{|c|c|c|c|c|c|c|c|c|c|}
\hline & $\mathrm{R} \dot{\mathrm{S}} \mathrm{L}_{\mathrm{TG}}$ & VLM (model/GNSS) & $\mathrm{A} \dot{\mathrm{S}} \mathrm{L}_{\mathrm{TG}}$ & IB & $\dot{N}$ & $\dot{M}$ & $\dot{\eta}$ & $\mathrm{A} \dot{S} L_{r}$ & $\mathrm{~A} \dot{S} L_{A}$ \\
\hline Nome & $2.0 \pm 1.4$ & $-1.1 \pm 0.9$ & $0.9 \pm 1.7$ & 0.1 & $1.1 \pm 0.4$ & $1.2 \pm 0.4$ & $1.7 \pm 3.0$ & $2.8 \pm 3.0$ & $0.2 \pm 2.8$ \\
\hline Prudhoe Bay & $1.7 \pm 0.8$ & $-1.4 \pm 1.3$ & $0.4 \pm 1.5$ & 0.4 & $1.0 \pm 0.5$ & $1.4 \pm 0.5$ & $5.7 \pm 3.2$ & $7.1 \pm 3.2$ & $1.1 \pm 3.0$ \\
\hline Reykjavik & $3.8 \pm 0.5$ & $0.0 \pm 0.3$ & $3.8 \pm 0.6$ & 1.0 & $0.3 \pm 0.7$ & $1.3 \pm 0.7$ & $-0.4 \pm 0.8$ & $0.9 \pm 1.0$ & $2.3 \pm 1.6$ \\
\hline Rørvik & $-0.7 \pm 0.7$ & $4.3 \pm 1.8$ & $3.6 \pm 1.9$ & 0.3 & $1.3 \pm 0.4$ & $1.5 \pm 0.4$ & $2.0 \pm 1.9$ & $3.5 \pm 1.9$ & $2.4 \pm 1.4$ \\
\hline Ny-Ålesund & $-7.4 \pm 0.5$ & $8.0 \pm 0.5$ & $0.5 \pm 0.7$ & 0.6 & $0.1 \pm 1.4$ & $0.7 \pm 1.4$ & $-2.0 \pm 0.6$ & $-1.3 \pm 1.5$ & $1.1 \pm 0.8$ \\
\hline Troms $\emptyset$ & $-0.1 \pm 0.6$ & $2.3 \pm 1.7$ & $2.2 \pm 1.8$ & 0.1 & $1.1 \pm 0.5$ & $1.3 \pm 0.5$ & $-0.1 \pm 1.0$ & $1.2 \pm 1.0$ & $2.2 \pm 1.1$ \\
\hline Vard $\varnothing$ & $-0.0 \pm 0.7$ & $2.5 \pm 1.4$ & $2.5 \pm 1.5$ & -0.1 & $1.2 \pm 0.5$ & $1.1 \pm 0.5$ & $0.6 \pm 1.2$ & $1.7 \pm 1.2$ & $4.1 \pm 1.1$ \\
\hline Amderma & $4.9 \pm 0.8$ & $0.2 \pm 1.1$ & $5.1 \pm 1.3$ & -0.1 & $1.1 \pm 0.4$ & $1.0 \pm 0.4$ & $3.9 \pm 3.5$ & $4.9 \pm 3.5$ & $-0.8 \pm 2.6$ \\
\hline Izvestia Tsik & $2.7 \pm 0.9$ & $2.3 \pm 1.5$ & $5.0 \pm 1.7$ & 0.2 & $1.1 \pm 0.6$ & $1.3 \pm 0.6$ & $-5.2 \pm 2.1$ & $-3.9 \pm 2.1$ & $1.0 \pm 3.2$ \\
\hline Golomianyi & $0.0 \pm 0.9$ & $2.8 \pm 2.3$ & $2.8 \pm 2.5$ & 0.6 & $0.9 \pm 0.9$ & $1.5 \pm 0.9$ & $-5.4 \pm 2.5$ & $-3.9 \pm 2.6$ & $-0.7 \pm 3.4$ \\
\hline Kotelnyi & $7.7 \pm 1.3$ & $-1.1 \pm 0.8$ & $6.5 \pm 1.5$ & 0.2 & $1.1 \pm 0.4$ & $1.4 \pm 0.4$ & $-7.5 \pm 3.8$ & $-6.1 \pm 3.8$ & $-0.8 \pm 3.3$ \\
\hline Kigiliah & $1.7 \pm 1.0$ & $-0.9 \pm 0.7$ & $0.8 \pm 1.3$ & -0.1 & $1.2 \pm 0.4$ & $1.0 \pm 0.4$ & $-7.9 \pm 3.8$ & $-6.8 \pm 3.8$ & $-1.6 \pm 3.0$ \\
\hline
\end{tabular}

residuals between the TG-observed ASL trend, $\mathrm{ASL}_{\mathrm{TG}}$ and

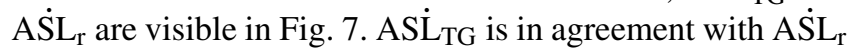
at only 5 of the 12 TGs $\left(8\right.$ of 12 for $\left.\mathrm{ASL}_{\mathrm{A}} / \mathrm{ASL}_{\mathrm{TG}}\right)$ within the combined standard error, while 9 are within 2 standard errors (95\% confidence interval). Relatively low standard errors of

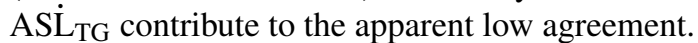

The Norwegian tide gauges (Rørvik, Troms $\varnothing$, Vard $\varnothing$, NyÅlesund) are together with Reykjavik the most consistent with the smallest errors. These are also the sites where $\mathrm{ASL}_{\mathrm{A}}$ and $\mathrm{ASL}_{\mathrm{r}}$ are most precise due to little or no sea ice and high density of hydrographical data (Fig. 3). For Rørvik and Vard $\varnothing, A \dot{S} L_{r}$ is more in alignment with $A \dot{S} L_{T G}$ than $A \dot{S} L_{A}$, while AS $\dot{L}_{T G}$ of Troms $\emptyset$ and Ny-Ålesund is better aligned with $A \dot{S} L_{A}$. We see that for Vardø and Rørvik, the $A \dot{S} L_{r}$ is split between a steric and a mass contribution of roughly the same size, which is similar to the contribution share of the global sea level trend (Church and White, 2011b; WCRP, 2018). At Troms $\varnothing$ a local negative halosteric trend (more saline water) is lowering $A \dot{S} L_{r}$, while for the area around 


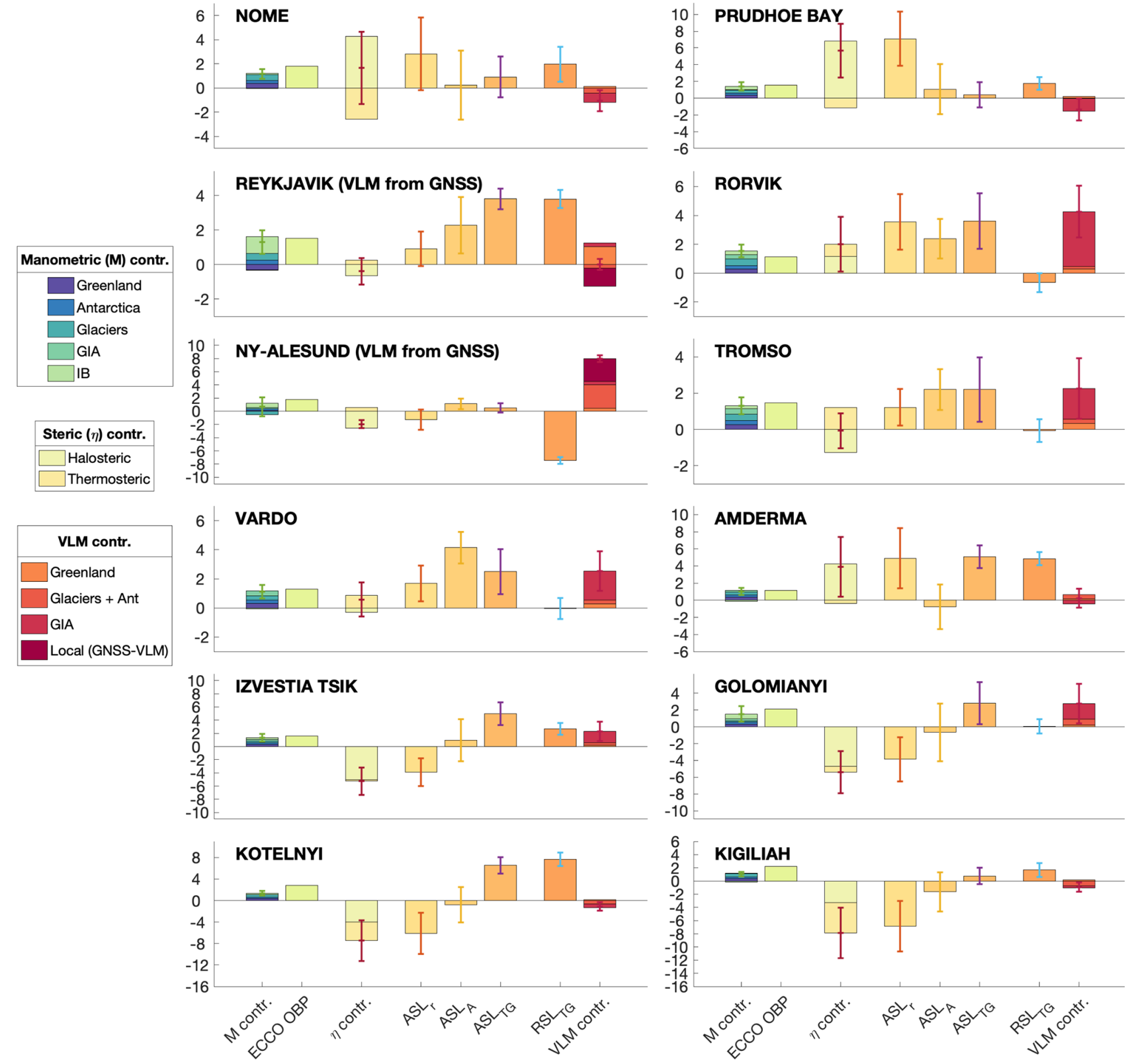

Figure 10. Components of sea level trend $\left[\mathrm{mm} \mathrm{yr}^{-1}\right]$ for each tide gauge from 1995-2015. The three bars in the middle $\left(A \dot{S} L_{r}, A \dot{S} L_{A}\right.$ and $A \dot{S} L_{T G}$ ) are the three independent estimates of absolute sea level. The error bars indicate 1 standard error (combined error from each component when relevant) equivalent to the $68 \%$ confidence level. The VLM component "local (GNSS-VLM)" is only relevant at Reykjavik and Ny-Ålesund because significant local properties cause VLM that is not present in the VLM model (Ludwigsen et al., 2020b). The glacier component of VLM includes the effect of rotational feedback, ocean loading and Antarctica, which is less than $0.5 \mathrm{~mm} \mathrm{yr}^{-1}$ combined.

Tromsø (50-200 km), AŚ $\mathrm{L}_{\mathrm{r}}$ agrees well with the observed $\mathrm{ASL}_{\mathrm{TG}}$ and $\mathrm{ASL}_{\mathrm{A}}$.

The Siberian coast has multiple river outlets that contribute significant fresh water to the Arctic Ocean (Proshutinsky et al., 2004; Morison et al., 2012; Armitage et al., 2016). A positive halosteric sea level trend is visible at the coast of the Bering and Kara Sea (Fig. 4), where the river OB has a major outflow. At the Amderma TG, which is located on the coast between the Barents and Kara Sea, an appar- ent large halosteric sea level fall is also recognized by the TG-measured sea level, despite rather large error bars due to lack of in situ data (Fig. 4). Ice loss from Novaya Zemlya contributes over $1 \mathrm{Gt}$ of fresh water to the Kara Sea every year, and the ice loss has been accelerating (Melkonian et al., 2016), but the contribution is small compared to the $+500 \mathrm{Gt}$ coming from the rivers every year. The halosteric signal could (falsely) be extrapolated from the Gulf of $\mathrm{Ob}$, which has major river outlets, and the agreement with $\mathrm{A} \dot{S} \mathrm{~L}_{\mathrm{TG}}$ 
is accidental. The halosteric sea level rise at Anderma remains doubtful, since $\mathrm{A} \dot{\mathrm{S}} \mathrm{L}_{\mathrm{A}}$ shows a negative ASL trend in opposition to $\mathrm{A} \dot{\mathrm{S}} \mathrm{L}_{\mathrm{TG}}$ and $\mathrm{A} \dot{\mathrm{S}} \mathrm{L}_{\mathrm{r}}$.

The four TGs along the eastern Siberian coast (Izvestia Tsik, Golomianyi, Kotelnyi, Kigiliah) all observe rising sea levels, while $\mathrm{A} \dot{\mathrm{S}} \mathrm{L}_{\mathrm{A}}$ and in particular $\mathrm{A} \dot{\mathrm{S}} \mathrm{L}_{\mathrm{r}}$ show a negative trend in the region. Missing data at the end of the time series of Golomianyi (Fig. 2) might significantly alter the observed trend. From 2005-2010, Golomanyi showed a sea level fall, while a few high measurements in 2012 and 2014 skew the trend upwards. Also, the TG at Izvestia Tsik observed a decreasing sea level from 2006/2007-2013, but an apparent steep sea level increase from 2013-2015 changes the trend to positive.

Non-seasonal variations in sea level in eastern Siberian seas are dominated by large-scale wind patterns controlled by the AO (Volkov and Landerer, 2013; Peralta-Ferriz et al., 2014; Armitage et al., 2018). These wind-driven sea level effects are largely manometric but are not included in the manometric estimate $(\dot{M})$. Wind-driven sea level change is part of ECCO OBP, which is $1-2 \mathrm{~mm} \mathrm{yr}^{-1}$ higher than $\dot{M}$ in the area (Fig. 5), while GRACE trends from 2003 to 2015 range from -2 (JPL) to +2 (GSFC) $\mathrm{mm} \mathrm{yr}^{-1}$ and might also be affected by leakage. $\mathrm{A} \dot{S} \mathrm{~L}_{\mathrm{TG}}$, however, is around $5 \mathrm{~mm} \mathrm{yr}^{-1}$ lower than $\mathrm{A} \dot{S} \mathrm{~L}_{\mathrm{r}}$ in the eastern Siberian Arctic and therefore not explained by the reconstructed manometric sea level difference to GRACE/ECCO.

The positive ASL trend among tide gauges in the eastern Russian Arctic is consistent with the results of other studies using an extended set of Russian tide gauges (Proshutinsky et al., 2004; Henry et al., 2012). Remarkably, the TG trend at Kotelnyi and Kigiliah differ by almost $6 \mathrm{~mm} \mathrm{yr}^{-1}$ (in total $12 \mathrm{~cm}$ difference over the time span of this study) despite being less than $250 \mathrm{~km}$ apart. From the time series in Fig. 2 a $30 \mathrm{~cm}$ RSL rise from 2002 to 2008 at Kotelnyi is visible. This significant change, however, is not observed by any altimeter product. A reasonable explanation can be local coastal subsidence caused by thawing of permafrost or oil depletion, which could also explain the mentioned sea level "jumps" of Golomanyi and Izvestia Tsik. This, however, is speculative, since it is not confirmed by any literature. In general, the poorest agreement is found at the Siberian TGs, which is similar to Armitage et al. (2016), who found that these tide gauges correlated the least with the altimetric observations. The sea level drop in the year 2000 observed by altimetry in East Siberian Sea (Fig. 7iii) is also to some extent seen by Kotelnyi and Kigiliah TGs (Fig. 2) that are located in the same region, which indicates that poor $T-S$ measurements in the region led to a false steric sea level high in the region from 1998-2002.

Nome and Prudhoe Bay in Alaska both show a positive steric TG trend, which is not reflected in $\mathrm{A} \dot{\mathrm{S}} \mathrm{L}_{\mathrm{TG}}$ or $\mathrm{A} \dot{\mathrm{S}} \mathrm{L}_{\mathrm{A}}$, thus resulting in a rather large discrepancy between $A \dot{S} L_{r}$ and $\mathrm{A} \dot{\mathrm{S}} \mathrm{L}_{\mathrm{A} / \mathrm{TG}}$. The strong halosteric trend of the Beaufort Gyre, might be extrapolated towards the Alaskan coastline and into the Bering Strait in the DTU steric model. There is no evidence in the literature for an extent of the Beaufort Gyre doming as shown from the halosteric trend, which indicates that the weighted spatial interpolation in combination with higher hydrographic data density in the Beaufort Sea creates this widening of the Beaufort Gyre.

Ny-Ålesund on Svalbard is dominated by a large VLM caused by recent deglaciation. This uplift completely mitigates the large sea level fall measured by the tide gauge and results in small rise of AS $\mathrm{L}_{\mathrm{TG}}$. In Ludwigsen et al. (2020a) it is argued that the discrepancy between GNSS and the VLM model in large part originates from VLM because of postLIA deglaciation on Svalbard (Rajner, 2018). This viscoelastic GIA-like LIA effect will certainly also have a gravitational sea level fingerprint $(\dot{N})$ that should be added to the manometric SLTs $\dot{M}$. This can explain some of the difference between $A \dot{S} L_{r}$ and $A \dot{S} L_{A} / T G$. A possibly positive dynamic $\dot{M}$ change (from the (ECCO OBP) $-\dot{M}$ difference in Fig. $5 \mathrm{~h}$ ) could further close the gap between $A \dot{S} L_{r}$ and $A \dot{S} L_{\mathrm{A} / T G}$.

None of the TG sites in this study experience a net sea level fall due to contemporary deglaciation and GIA $(\dot{N}$ in Table 1), and only Ny-Ålesund $\left(-0.4 \mathrm{~mm} \mathrm{yr}^{-1}\right)$ and Reykjavik $\left(-0.2 \mathrm{~mm} \mathrm{yr}^{-1}\right)$ will experience a small sea level fall from contemporary deglaciation alone. So even though the Arctic is heavily prone to ice mass loss and thus a weakened gravitational pull, the Arctic as a region is not experiencing an absolute sea level fall from contemporary deglaciation. On the contrary, it causes the sea level to rise at around $1 \mathrm{~mm} \mathrm{yr}^{-1}$ in most of the Arctic. However, by accounting for the deglaciation effect on VLM, contemporary deglaciation will contribute to a relative sea level fall in most areas of the Arctic.

\section{Uncertainty of the contributions}

The uncertainties of the trend estimates for RSL $\mathrm{TG}_{\mathrm{TG}}$, VLM, the gravitational fingerprint $(N)$ and steric $(\eta)$ in Table 1 and Fig. 10 are derived as the standard error of the detrended and deseasoned time series of the contributions. GIA (Caron et al., 2018) and altimetry (Rose et al., 2019) have an associated uncertainty that is used. For the VLM model a $10 \%$ error is added to account for uncertainties of the Earth model (Wang et al., 2012).

The spatial distribution of the uncertainties is shown in Fig. 11. Generally, the largest uncertainties are found along the Siberian coast, with the steric uncertainty in most cases being the largest source of uncertainty (Fig. 10). The standard error naturally reflects whether the steric heights are unstable and poorly constrained (if, for example, there are few hydrographic data; Fig. 3). In principle, this method requires temporal independence, which is not entirely true, since outliers are replaced with data from adjacent years. Furthermore, a large influence by the non-periodic and nonlinear Arctic Oscillation would enhance the uncertainty, even though this 

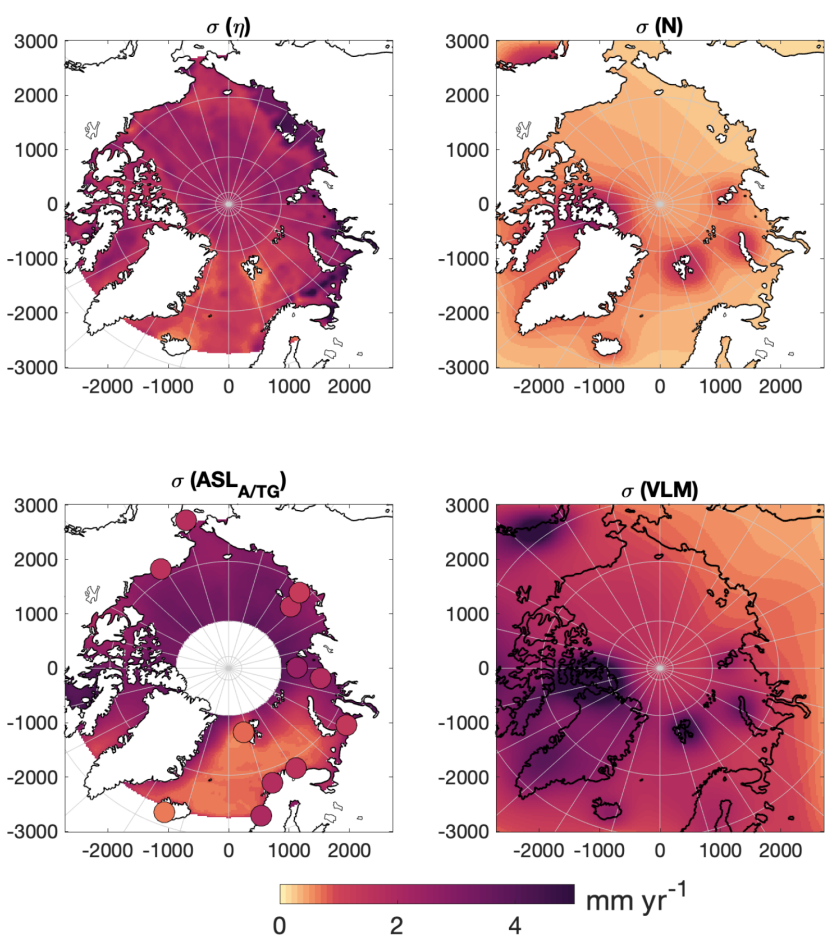

Figure 11. Standard error ( $68 \%$ confidence interval) of the 19952015 trend $\left[\mathrm{mm} \mathrm{yr}^{-1}\right.$ ] for combined steric, combined $\dot{N}, \mathrm{~A} \dot{S} L_{\mathrm{A} / \mathrm{TG}}$ and combined VLM contributions.

is a real physical signal. Thereby, the estimated error is a composite of uncertainties originating from the way the sea level component is constructed and from interannual variability.

The mass contribution and VLM naturally have the largest uncertainties close to glaciated areas. Glacial ice loss on Baffin Island is poorly constrained in the ice model, which is reflected with large uncertainties in this area. The uncertainty of altimetry reflects the data availability of areas with sea ice contrary to the ice-free ocean, while the largest uncertainties of the TGs are those with the largest interannual variability.

\section{Conclusion}

All significant contributions to the sea level change from 1995-2015 in the Arctic Ocean were mapped and assessed at 12 tide gauges located throughout the Arctic Ocean. As the first study, the observed sea level was attempted to be reconstructed without the use of GRACE data or modeled steric data in a region where observations are sparse and very uncertain. Thus, is it possible to attribute the observed sea level changes to their origin and understand the components of the altimetry and TG-observed sea level trend.

Figure 7 shows that the spatial pattern of the altimetryobserved sea level trend $\left(\mathrm{A} \dot{S} L_{\mathrm{A}}\right)$ is generally restored from the reconstructed trend estimate $\left(\mathrm{ASL}_{r}\right)$. The spatial corre- lation between the reconstructed trend map and altimetryderived trend $(R=0.50)$ from 1995-2015 outperforms a similar analysis for GRACE-based reconstructions from 2003-2015 ( $R=0.34-0.37$ ); however, when using the reconstructed manometric sea level component instead of GRACE, a similar correlation is reached $(R=0.38)$. Hence, the calculated manometric contribution is an equal alternative to GRACE that should be considered for studying long-term past and future Arctic sea level change.

Figure 9 shows the residual between observed sea level ( $\mathrm{A} \dot{S} \mathrm{~L}_{\mathrm{A} / \mathrm{TG}}$ ) and the reconstructed ASL estimate within the combined uncertainty. The reconstructed ASL trend agrees with altimetry in $87 \%$ of the area within the $68 \%$ confidence level (96\% of the area within the $95 \%$ confidence level). The residual map indicates an improvement over previous studies (Carret et al., 2017; Raj et al., 2020); however, this assessment is only qualitative since different subsets of periods are used. The two major residuals between altimetry and the reconstructed product are found in the Beaufort Sea and East Siberian Sea. In both regions, the altimetry estimate by Armitage et al. (2016) has better agreement than the DTU/TUM altimetry product used. A dominant halosteric trend in the Beaufort Sea that is larger than the altimetric trend is also observed by Carret et al. (2017) and Raj et al. (2020).

The sea level trend at 5 (9 using the $95 \%$ confidence interval) of the 12 VLM-corrected TGs agrees with the reconstruction, while 8 of 12 TGs agree with altimetry. The relatively poor correlation at TG sites can be attributed to sparse $T-S$ data to compute steric sea level along the coast of the Beaufort Sea and the Siberian Arctic as well as possible local unknown land subsidence and uplift affecting the tide gauge record.

From Figs. 10 and 11 it is evident that the steric estimate is the main source of uncertainty. Some areas, in particular the Norwegian Sea, have more observations (from both altimetry and hydrographic data), and thus the individual contributions are estimated with lower uncertainty. The Siberian seas, however, are poorly constrained with observations, and the steric product as well as the altimetry and tide gauges show large uncertainties. The manometric sea level change has a more uniform and smaller contribution to ASL with smaller associated uncertainties compared to the steric component. However, considering the difference to GRACE estimates and the modeled ECCO estimate, the uncertainty of the total manometric contribution is also significant, and the reasons are not yet resolved. Except for the central Arctic Ocean, where GRACE is less affected by leakage-related issues, GRACE is not able to explain the obtained residuals.

Generally, the Arctic sea level reconstruction would be improved if the steric estimate were further constrained, since it is the dominant feature of Arctic Ocean sea level change. Eventually integrating sea surface temperature and salinity from satellite observations could improve the estimates in areas with few in situ data. Furthermore, an independent estimate of the dynamic contribution to manometric sea level 
change is needed to include the significant wind-driven sea level changes in the Arctic.

Code and data availability. The tide gauge sea level time series is available at http://www.psmsl.org/data/obtaining/ (PSMSL, 2020), and the VLM model is available at https://doi.org/10.11583/DTU.12554489.v1 (Ludwigsen et al., 2020b). DTU steric is available at ftp://ftp.space. dtu.dk/pub/DTU19/STERIC/ (Ludwigsen and Andersen, 2020), and the REAR software is available from GitHub at https://github.com/danielemelini/rear (Melini et al., 2014).

Author contributions. CBL was responsible for the method, concept, data analysis and writing. OBA was responsible for the concept and editing. SKR was responsible for providing altimetry data, validation and editing.

Competing interests. The contact author has declared that neither they nor their co-authors have any competing interests.

Disclaimer. Publisher's note: Copernicus Publications remains neutral with regard to jurisdictional claims in published maps and institutional affiliations.

Special issue statement. This article is part of the special issue "Towards an integrated Arctic observation system to fill gaps of observing system across the atmosphere, ocean, cryosphere, geosphere, and terrestrial ecosystems". It is not associated with a conference.

Acknowledgements. The authors want to thank three anonymous reviewers for their comments that greatly improved the paper. Furthermore, we thank Lambert Caron for providing the Caron2018 GIA model, available at https://vesl.jpl.nasa.gov/solid-earth/gia/ (last access: 10 July 2021), and Danielle Melini for creating the REAR code (Melini et al., 2014).

Financial support. This research has been supported by Horizon 2020 INTAROS (grant no. 727890) and the ESA Climate Change Initiative sea level budget closure (grant no. Expro RFP/314679/16/INB).

Review statement. This paper was edited by Anne Marie Tréguier and reviewed by three anonymous referees.

\section{References}

Andersen, O., Knudsen, P., and Stenseng, L.: A New DTU18 MSS Mean Sea Surface - Improvement from SAR Altimetry, 25 years of progress in radar altimetry symposium, Ponta Delgada, São
Miguel Island, Azores Archipelago, Portugal, 24 to 29 September 2018, p. 172, 2018.

Armitage, T. W. K., Bacon, S., Ridout, A. L., Thomas, S. F., Aksenov, Y., and Wingham, D. J.: Arctic sea surface height variability and change from satellite radar altimetry and GRACE, 2003-2014, J. Geophys. Res.-Oceans, 121, 4303-4322, https://doi.org/10.1002/2015JC011579, 2016.

Armitage, T. W. K., Bacon, S., and Kwok, R.: Arctic Sea Level and Surface Circulation Response to the Arctic Oscillation, Geophys. Res. Lett., 45, 6576-6584, https://doi.org/10.1029/2018GL078386, 2018.

Bamber, J. and Riva, R.: The sea level fingerprint of recent ice mass fluxes, The Cryosphere, 4, 621-627, https://doi.org/10.5194/tc4-621-2010, 2010.

Behrendt, A., Sumata, H., Rabe, B., and Schauer, U.: UDASH Unified Database for Arctic and Subarctic Hydrography, Earth Syst. Sci. Data, 10, 1119-1138, https://doi.org/10.5194/essd-101119-2018, 2018.

Bonin, J. A., Bettadpur, S., and Tapley, B. D.: High-frequency signal and noise estimates of CSR GRACE RL04, J. Geodesy, 86, 1-13, https://doi.org/10.1007/s00190-012-0572-5, 2012.

Box, J. E., Colgan, W. T., Christensen, T. R., Schmidt, N. M., Lund, M., Parmentier, F. J. W., Brown, R., Bhatt, U. S., Euskirchen, E. S., Romanovsky, V. E., Walsh, J. E., Overland, J. E., Wang, M., Corell, R. W., Meier, W. N., Wouters, B., Mernild, S., Mård, J., Pawlak, J., and Olsen, M. S.: Key indicators of Arctic climate change: 1971-2017, Environ. Res. Lett., 14, 045010, https://doi.org/10.1088/1748-9326/aafc1b, 2019.

Calafat, F. M., Chambers, D. P., and Tsimplis, M. N.: Mechanisms of decadal sea level variability in the eastern North Atlantic and the Mediterranean Sea, J. Geophys. Res.-Oceans, 117, C09022, https://doi.org/10.1029/2012JC008285, 2012.

Caron, L., Ivins, E. R., Larour, E., Adhikari, S., Nilsson, J., and Blewitt, G.: GIA Model Statistics for GRACE Hydrology, Cryosphere, and Ocean Science, Geophys. Res. Lett., 45, 22032212, https://doi.org/10.1002/2017GL076644, 2018.

Carret, A., Johannessen, J. A., Andersen, O. B., Ablain, M., Prandi, P., Blazquez, A., and Cazenave, A.: Arctic Sea Level During the Satellite Altimetry Era, Survey. Geophys., 38, 251-275, https://doi.org/10.1007/s10712-016-9390-2, 2017.

Chambers, D. P. and Bonin, J. A.: Evaluation of Release-05 GRACE time-variable gravity coefficients over the ocean, Ocean Sci., 8 , 859-868, https://doi.org/10.5194/os-8-859-2012, 2012.

Cheng, Y., Andersen, O., and Knudsen, P.: An Improved 20-Year Arctic Ocean Altimetric Sea Level Data Record, Mar. Geod., 38, 146-162, https://doi.org/10.1080/01490419.2014.954087, 2015.

Church, J. and White, N.: Sea-Level Rise from the Late 19th to the Early 21st Century, Survey. Geophys., 32, 585602, https://doi.org/10.1007/s10712-011-9119-1, cited By 737, 2011a.

Church, J. A. and White, N. J.: Sea-Level Rise from the Late 19th to the Early 21st Century, Survey. Geophys., 32, 585-602, https://doi.org/10.1007/s10712-011-9119-1, 2011b.

Dangendorf, S., Hay, C., Calafat, F. M., Marcos, M., Piecuch, C. G., Berk, K., and Jensen, J.: Persistent acceleration in global sea-level rise since the 1960s, Nat. Clim. Change, 9, 705-710, https://doi.org/10.1038/s41558-019-0531-8, 2019.

Forget, G., Campin, J.-M., Heimbach, P., Hill, C. N., Ponte, R. M., and Wunsch, C.: ECCO version 4: an integrated framework for 
non-linear inverse modeling and global ocean state estimation, Geosci. Model Dev., 8, 3071-3104, https://doi.org/10.5194/gmd8-3071-2015, 2015.

Frederikse, T., Riva, R. E. M., and King, M. A.: Ocean Bottom Deformation Due To Present-Day Mass Redistribution and Its Impact on Sea Level Observations, Geophys. Res. Lett., 44, 1230612314, https://doi.org/10.1002/2017GL075419, 2017.

Frederikse, T., Landerer, F. W., and Caron, L.: The imprints of contemporary mass redistribution on local sea level and vertical land motion observations, Solid Earth, 10, 1971-1987, https://doi.org/10.5194/se-10-1971-2019, 2019.

Frederikse, T., Landerer, F., Caron, L., Adhikari, S., Parkes, D., Humphrey, V. W., Dangendorf, S., Hogarth, P., Zanna, L., Cheng, L., and Wu, Y. H.: The causes of sea-level rise since 1900, Nature, 584, 393-397, https://doi.org/10.1038/s41586-020-2591-3, 2020.

Fukumori, I., Wang, O., Fenty, I., Forget, G., Heimbach, P., and Ponte, R. M.: ECCO Version 4 Release 4 Dataset, PO.DAAC, CA, USA, available at: https://podaac.jpl.nasa.gov/ECCO (last access: 25 June 2020), 2019.

Giles, K. A., Laxon, S. W., Ridout, A. L., Wingham, D. J., and Bacon, S.: Western Arctic Ocean freshwater storage increased by wind-driven spin-up of the Beaufort Gyre, Nat. Geosci., 5, 194197, https://doi.org/10.1038/ngeo1379, 2012.

Gill, A. and Niller, P.: The theory of the seasonal variability in the ocean, Deep Sea Research and Oceanographic Abstracts, 20, 141-177, https://doi.org/10.1016/0011-7471(73)90049-1, 1973.

Gregory, J. M., Griffies, S. M., Hughes, C. W., Lowe, J. A., Church, J. A., Fukimori, I., Gomez, N., Kopp, R. E., Landerer, F., Cozannet, G. L., Ponte, R. M., Stammer, D., Tamisiea, M. E., and van de Wal, R. S. W.: Concepts and Terminology for Sea Level: Mean, Variability and Change, Both Local and Global, Survey. Geophys., 40, 1251-1289, https://doi.org/10.1007/s10712-01909525-z, 2019.

Henry, O., Prandi, P., Llovel, W., Cazenave, A., Jevrejeva, S., Stammer, D., Meyssignac, B., and Koldunov, N.: Tide gaugebased sea level variations since 1950 along the Norwegian and Russian coasts of the Arctic Ocean: Contribution of the steric and mass components, J. Geophys. Res.-Oceans, 117, C06023, https://doi.org/10.1029/2011JC007706, 2012.

Holgate, S. J., Matthews, A., Woodworth, P. L., Rickards, L. J., Tamisiea, M. E., Bradshaw, E., Foden, P. R., Gordon, K. M., Jevrejeva, S., and Pugh, J.: New Data Systems and Products at the Permanent Service for Mean Sea Level, J. Coastal Res., 29, 493504, https://doi.org/10.2112/JCOASTRES-D-12-00175.1, 2012.

Khan, S. A., Sasgen, I., Bevis, M., van Dam, T., Bamber, J. L., Wahr, J., Willis, M., Kjær, K. H., Wouters, B., Helm, V., Csatho, B., Fleming, K., Bjørk, A. A., Aschwanden, A., Knudsen, P., and Munneke, P. K.: Geodetic measurements reveal similarities between post-Last Glacial Maximum and present-day mass loss from the Greenland ice sheet, Science Advances, 2, https://doi.org/10.1126/sciadv.1600931, 2016.

King, M. A., Keshin, M., Whitehouse, P. L., Thomas, I. D., Milne, G., and Riva, R. E. M.: Regional biases in absolute sealevel estimates from tide gauge data due to residual unmodeled vertical land movement, Geophys. Res. Lett., 39, L14604, https://doi.org/10.1029/2012GL052348, 2012.

Kustowski, B., Dziewoński, A. M., and Ekström, G.: Nonlinear Crustal Corrections for Normal-Mode Seismograms, B. Seismol.
Soc. Am., 97, 1756-1762, https://doi.org/10.1785/0120070041, 2007.

Laxon, S., Peacock, H., and Smith, D.: High interannual variability of sea ice thickness in the Arctic region, Nature, 425, 947-950, https://doi.org/10.1038/nature02050, 2003.

Limkilde Svendsen, P., Andersen, O. B., and Aasbjerg Nielsen, A.: Stable reconstruction of Arctic sea level for the 1950 2010 period, J. Geophys. Res.-Oceans, 121, 5697-5710, https://doi.org/10.1002/2016JC011685, 2016.

Loomis, B. D., Luthcke, S. B., and Sabaka, T. J.: Regularization and error characterization of GRACE mascons, J. Geodesy, 93 1381-1398, https://doi.org/10.1007/s00190-019-01252-y, 2019.

Ludwigsen, C. A. and Andersen, O. B.: Contributions to Arctic sea level from 2003 to 2015, Adv. Space Res., 68, 703-710, https://doi.org/10.1016/j.asr.2019.12.027, 2020.

Ludwigsen, C. A. and Andersen, O. B., Arctic steric sea level change, Technical University of Denmark, available at: ftp:// ftp.space.dtu.dk/pub/DTU19/STERIC/, last access: 15 September 2020.

Ludwigsen, C. A., Khan, S. A., Andersen, O. B., and Marzeion, B.: Vertical Land Motion From Present-Day Deglaciation in the Wider Arctic, Geophys. Res. Lett., 47, e2020GL088144, https://doi.org/10.1029/2020GL088144, 2020a.

Ludwigsen, C. A., Andersen, O. B., and Khan, S. A.: Arctic Vertical Land Motion $(5 \times 5 \mathrm{~km})$ (Version 1$)$, Technical University of Denmark, https://doi.org/10.11583/DTU.12554489.v1, 2020b.

Luthcke, S. B., Sabaka, T., Loomis, B., Arendt, A., McCarthy, J., and Camp, J.: Antarctica, Greenland and Gulf of Alaska land-ice evolution from an iterated GRACE global mascon solution, J. Glaciol., 59, 613-631, https://doi.org/10.3189/2013JoG12J147, 2013.

Marzeion, B., Jarosch, A. H., and Hofer, M.: Past and future sealevel change from the surface mass balance of glaciers, The Cryosphere, 6, 1295-1322, https://doi.org/10.5194/tc-6-12952012, 2012.

Melini, D., Gegout, P., Spada, G., and King, M.: REAR - a regional ElAstic Rebound calculator, User manual for version 1.0, Istituto Nazionale di Geofisica e Vulcanologia, GitHub, available at: https://github.com/danielemelini/rear (last access: 10 December 2020), 2014.

Melkonian, A. K., Willis, M. J., Pritchard, M. E., and Stewart, A. J.: Recent changes in glacier velocities and thinning at Novaya Zemlya, Remote Sens. Environ., 174, 244-257, https://doi.org/10.1016/j.rse.2015.11.001, 2016.

Mitrovica, J. X., Gomez, N., Morrow, E., Hay, C., Latychev, K., and Tamisiea, M. E.: On the robustness of predictions of sea level fingerprints, Geophys. J. Int., 187, 729-742, https://doi.org/10.1111/j.1365-246X.2011.05090.x, 2011.

Morison, J., Kwok, R., Peralta-Ferriz, C., Alkire, M., Rigor, I., Andersen, R., and Steele, M.: Changing Arctic Ocean freshwater pathways, Nature, 481, 66-70, https://doi.org/10.1038/nature10705, 2012.

$\mathrm{Mu}, \mathrm{D} ., \mathrm{Xu}, \mathrm{T}$., and $\mathrm{Xu}, \mathrm{G}$. : Improved Arctic Ocean Mass Variability Inferred from Time-Variable Gravity with Constraints and Dual Leakage Correction, Mar. Geod., 43, 269-284, https://doi.org/10.1080/01490419.2020.1711832, 2020.

Naeije, M., Schrama, E., and Scharroo, R.: The Radar Altimeter Database System project RADS, Igarss 2000: Ieee 2000 International Geoscience and Remote Sens- 
ing Symposium, Vol. I-Vi, Proceedings, 487-490, https://doi.org/10.1109/IGARSS.2000.861605, 2000.

Peacock, N. R. and Laxon, S. W.: Sea surface height determination in the Arctic Ocean from ERS altimetry, J. Geophys. Res.-Oceans, 109, C07001 1-14, https://doi.org/10.1029/2001JC001026, 2004.

Peltier, W.: Closure of the budget of global sea level rise over the GRACE era: the importance and magnitudes of the required corrections for global glacial isostatic adjustment, Quaternary Sci. Rev., 28, 1658-1674, https://doi.org/10.1016/j.quascirev.2009.04.004, Quaternary Ice Sheet-Ocean Interactions and Landscape Responses, 2009.

Peralta-Ferriz, C. and Morison, J.: Understanding the annual cycle of the Arctic Ocean bottom pressure, Geophys. Res. Lett., 37, L10603, https://doi.org/10.1029/2010GL042827, 2010.

Peralta-Ferriz, C., Morison, J. H., Wallace, J. M., Bonin, J. A., and Zhang, J.: Arctic ocean circulation patterns revealed by GRACE, J. Climate, 27, 1445-1468, https://doi.org/10.1175/JCLI-D-1300013.1, 2014.

Permanent Service for Mean Sea Level (PSMSL): Tide Gauge Data, available at: http://www.psmsl.org/data/obtaining/, last access: 10 August 2020.

Prandi, P., Ablain, M., Cazenave, A., and Picot, N.: A New Estimation of Mean Sea Level in the Arctic Ocean from Satellite Altimetry, Mar. Geod., 35, 61-81, https://doi.org/10.1080/01490419.2012.718222, 2012.

Proshutinsky, A., Ashik, I. M., Dvorkin, E. N., Häkkinen, S., Krishfield, R. A., and Peltier, W. R.: Secular sea level change in the Russian sector of the Arctic Ocean, J. Geophys. Res.-Oceans, 109, C03042, https://doi.org/10.1029/2003JC002007, 2004.

Proshutinsky, A., Krishfield, R., Timmermans, M.-L., Toole, J., Carmack, E., McLaughlin, F., Williams, W. J., Zimmermann, S., Itoh, M., and Shimada, K.: Beaufort Gyre freshwater reservoir: State and variability from observations, J. Geophys. Res.Oceans, 114, C00A10, https://doi.org/10.1029/2008JC005104, 2009.

Proshutinsky, A., Dukhovskoy, D., Timmermans, M. L., Krishfield, R., and Bamber, J. L.: Arctic circulation regimes, Philos. T. R. Soc. A, 373, 20140160, https://doi.org/10.1098/rsta.2014.0160, 2015.

Proshutinsky, A., Krishfield, R., Toole, J. M., Timmermans, M.-L., Williams, W., Zimmermann, S., Yamamoto-Kawai, M., Armitage, T. W. K., Dukhovskoy, D., Golubeva, E., Manucharyan, G. E., Platov, G., Watanabe, E., Kikuchi, T., Nishino, S., Itoh, M., Kang, S.-H., Cho, K.-H., Tateyama, K., and Zhao, J.: Analysis of the Beaufort Gyre Freshwater Content in 2003-2018, J. Geophys. Res.-Oceans, 124, 9658-9689, https://doi.org/10.1029/2019JC015281, 2019.

Pugh, D. and Woodworth, P.: Sea-Level Science: Understanding Tides, Surges, Tsunamis and Mean Sea-Level Changes, Cambridge University Press, Cambridge, England, https://doi.org/10.1017/CBO9781139235778, 2014.

Raj, R. P., Andersen, O. B., Johannessen, J. A., Gutknecht, B. D., Chatterjee, S., Rose, S. K., Bonaduce, A., Horwath, M., Ranndal, H., Richter, K., Palanisamy, H., Ludwigsen, C. A., Bertino, L., Nilsen, J. E. O., Knudsen, P., Hogg, A., Cazenave, A., and Benveniste, J.: Arctic Sea level Budget Assessment During the GRACE/Argo Time Period, Remote Sens.-Basel, 12, 2837, https://doi.org/10.3390/rs12172837, 2020.
Rajner, M.: Detection of ice mass variation using gnss measurements at Svalbard, J. Geodyn., 121, 20-25, https://doi.org/10.1016/j.jog.2018.06.001, 2018.

Ricker, R., Hendricks, S., and Beckers, J. F.: The impact of geophysical corrections on sea-ice freeboard retrieved from satellite altimetry, Remote Sens.-Basel, 8, 317, https://doi.org/10.3390/rs8040317, 2016.

Roquet, F., Madec, G., McDougall, T. J., and Barker, P. M.: Accurate polynomial expressions for the density and specific volume of seawater using the TEOS-10 standard, Ocean Model., 90, 2943, https://doi.org/10.1016/j.ocemod.2015.04.002, 2015.

Rose, S. K., Andersen, O., Passaro, M., Ludwigsen, C., and Schwatke, C.: Arctic Ocean Sea Level Record from the Complete Radar Altimetry Era: 1991-2018, Remote Sens.-Basel, 11, 1672, https://doi.org/10.3390/rs11141672, 2019.

Royston, S., Dutt Vishwakarma, B., Westaway, R., Rougier, J., Sha, Z., and Bamber, J.: Can We Resolve the BasinScale Sea Level Trend Budget From GRACE Ocean Mass?, J. Geophys. Res.-Oceans, 125, e2019JC015535, https://doi.org/10.1029/2019JC015535, 2020.

Santamaría-Gómez, A., Gravelle, M., Dangendorf, S., Marcos, M., Spada, G., and Wöppelmann, G.: Uncertainty of the 20th century sea-level rise due to vertical land motion errors, Earth Planet. Sc. Lett., 473, 24-32, https://doi.org/10.1016/j.epsl.2017.05.038, 2017.

Save, H., Bettadpur, S., and Tapley, B. D.: High-resolution CSR GRACE RL05 mascons, J. Geophys. Res.-Sol. Ea., 121, 75477569, https://doi.org/10.1002/2016JB013007, 2016.

Schröder, L., Horwath, M., Dietrich, R., Helm, V., van den Broeke, M. R., and Ligtenberg, S. R. M.: Four decades of Antarctic surface elevation changes from multi-mission satellite altimetry, The Cryosphere, 13, 427-449, https://doi.org/10.5194/tc-13427-2019, 2019.

Shepherd, A., Ivins, E., Rignot, E., Smith, B., van den Broeke, M., Velicogna, I., Whitehouse, P. L., Briggs, K., Joughin, I., Krinner, G., Nowicki, S., Payne, T., Scambos, T., Schlegel, N., A, G., Agosta, C., Ahlstrøm, A., Babonis, G., Barletta, V., Blazquez, A., Bonin, J., Csatho, B., Cullather, R., Felikson, D., Fettweis, X., Forsberg, R., Gallee, H., Gardner, A., Gilbert, L., Groh, A., Gunter, B., Hanna, E., Harig, C., Helm, V., Horvath, A., Horwath, M., Khan, S., K. Kjeldsen, K., Konrad, H., Langen, P., Lecavalier, B., Loomis, B., Luthcke, S., McMillan, M., Melini, D., Mernild, S., Mohajerani, Y., Moore, P., Mouginot, J., Moyano, G., Muir, A., Nagler, T., Nield, G., Nilsson, J., Noel, B., Otosaka, I., E. Pattle, M., Peltier, W. R., Pie, N., Rietbroek, R., Rott, H., Sandberg-Sørensen, L., Sasgen, I., Save, H., Scheuchl, B., Schrama, E., Schröder, L., Seo, K.-W., Simonsen, S., Slater, T., Spada, G., Sutterley, T., Talpe, M., Tarasov, L., van de Berg, W. J., van der Wal, W., van Wessem, M., Dutt Vishwakarma, B., Wiese, D., and Wouters, B. (The IMBIE Team): Mass balance of the Antarctic Ice Sheet from 1992 to 2017, Nature, 558, 219-222, https://doi.org/10.1038/s41586-018-0179-y, 2018.

Shepherd, A., Ivins, E., Rignot, E., Smith, B., van den Broeke, M., Velicogna, I., Whitehouse, P., Briggs, K., Joughin, I., Krinner, G., Nowicki, S., Payne, T., Scambos, T., Schlegel, N., Geruo, A., Agosta, C., Ahlstrøm, A., Babonis, G., Barletta, V. R., Bjørk, A. A., Blazquez, A., Bonin, J., Colgan, W., Csatho, B., Cullather, R., Engdahl, M. E., Felikson, D., Fettweis, X., Forsberg, R., Hogg, A. E., Gallee, H., Gardner, A., Gilbert, L., Gourmelen, 
N., Groh, A., Gunter, B., Hanna, E., Harig, C., Helm, V., Horvath, A., Horwath, M., Khan, S., Kjeldsen, K. K., Konrad, H., Langen, P. L., Lecavalier, B., Loomis, B., Luthcke, S., McMillan, M., Melini, D., Mernild, S., Mohajerani, Y., Moore, P., Mottram, R., Mouginot, J., Moyano, G., Muir, A., Nagler, T., Nield, G., Nilsson, J., Noël, B., Otosaka, I., Pattle, M. E., Peltier, W. R., Pie, N., Rietbroek, R., Rott, H., Sørensen, L. S., Sasgen, I., Save, H., Scheuchl, B., Schrama, E., Schröder, L., Seo, K.-W., Simonsen, S. B., Slater, T., Spada, G., Sutterley, T., Talpe, M., Tarasov, L., Jan van de Berg, W., van der Wal, W., van Wessem, M., Vishwakarma, B. D., Wiese, D., Wilton, D., Wagner, T., Wouters, B., and Wuite, J. (The IMBIE Team): Mass balance of the Greenland Ice Sheet from 1992 to 2018, Nature, 579, 233 239, https://doi.org/10.1038/s41586-019-1855-2, 2020.

Smith, G. C., Allard, R., Babin, M., Bertino, L., Chevallier, M., Corlett, G., Crout, J., Davidson, F., Delille, B., Gille, S. T., Hebert, D., Hyder, P., Intrieri, J., Lagunas, J., Larnicol, G., Kaminski, T., Kater, B., Kauker, F., Marec, C., Mazloff, M., Metzger, E. J., Mordy, C., O'Carroll, A., Olsen, S. M., Phelps, M., Posey, P., Prandi, P., Rehm, E., Reid, P., Rigor, I., Sandven, S., Shupe, M., Swart, S., Smedstad, O. M., Solomon, A., Storto, A., Thibaut, P., Toole, J., Wood, K., Xie, J., Yang, Q., and the WWRP PPP Steering Group: Polar Ocean Observations: A Critical Gap in the Observing System and Its Effect on Environmental Predictions From Hours to a Season, Front. Mar. Sci., 6, 429, https://doi.org/10.3389/fmars.2019.00429, 2019.

Spada, G.: Glacial Isostatic Adjustment and Contemporary Sea Level Rise: An Overview, Survey. Geophys., 38, 153-185, https://doi.org/10.1007/s10712-016-9379-x, 2017.

Stammer, D.: Steric and wind-induced changes in TOPEX/POSEIDON large-scale sea surface topography observations, J. Geophys. Res.-Oceans, 102, 20987-21009, https://doi.org/10.1029/97JC01475, 1997.

Stammer, D., Ray, R. D., Andersen, O. B., Arbic, B. K., Bosch, W., Carrère, L., Cheng, Y., Chinn, D. S., Dushaw, B. D., Egbert, G. D., Erofeeva, S. Y., Fok, H. S., Green, J. A. M., Griffiths, S., King, M. A., Lapin, V., Lemoine, F. G., Luthcke, S. B., Lyard, F., Morison, J., Müller, M., Padman, L., Richman, J. G., Shriver, J. F., Shum, C. K., Taguchi, E., and Yi, Y.: Accuracy assessment of global barotropic ocean tide models, Rev. Geophys., 52, 243282, https://doi.org/10.1002/2014rg000450, 2014.

Tapley, B. D., Bettadpur, S., Watkins, M., and Reigber, C.: The gravity recovery and climate experiment: Mission overview and early results, Geophys. Res. Lett., 31, L09607, https://doi.org/10.1029/2004GL019920, 2004. van Dam, T., Collilieux, X., Wuite, J., Altamimi, Z., and Ray, J.: Nontidal ocean loading: amplitudes and potential effects in GPS height time series, J. Geodesy, 86, 1043-1057, https://doi.org/10.1007/s00190-012-0564-5, 2012.

Volkov, D. L. and Landerer, F. W.: Nonseasonal fluctuations of the Arctic Ocean mass observed by the GRACE satellites, J. Geophys. Res.-Oceans, 118, 6451-6460, https://doi.org/10.1002/2013JC009341, 2013.

Wang, H., Xiang, L., Jia, L., Jiang, L., Wang, Z., Hu, B., and Gao, P.: Load Love numbers and Green's functions for elastic Earth models PREM, iasp91, ak135, and modified models with refined crustal structure from Crust 2.0, Comput.Geosci., 49, 190-199, https://doi.org/10.1016/j.cageo.2012.06.022, 2012.

Watkins, M. M., Wiese, D. N., Yuan, D.-N., Boening, C., and Landerer, F. W.: Improved methods for observing Earth's time variable mass distribution with GRACE using spherical cap mascons, J. Geophys. Res.-Sol. Ea., 120, 2648-2671, https://doi.org/10.1002/2014JB011547, 2015.

WCRP Global Sea Level Budget Group: Global sea-level budget 1993-present, Earth Syst. Sci. Data, 10, 1551-1590, https://doi.org/10.5194/essd-10-1551-2018, 2018.

Wiese, D. N., Yuan, D. N., Boening, C., and Landerer, Felix W.and Watkins, M. M.: JPL GRACE and GRACE-FO Mascon Ocean, Ice, and Hydrology Equivalent Water Height Coastal Resolution Improvement (CRI) Filtered Release 06 Version 02, PO.DAAC, CA, USA, https://doi.org/10.5067/TEMSC-3JC62, 2019.

Wöppelmann, G. and Marcos, M.: Vertical land motion as a key to understanding sea level change and variability, Rev. Geophys., 54, 64-92, https://doi.org/10.1002/2015RG000502, 2016.

Zemp, M., Huss, M., Thibert, E., Eckert, N., McNabb, R., Huber, J., Barandun, M., Machguth, H., Nussbaumer, S. U., GärtnerRoer, I., Thomson, L., Paul, F., Maussion, F., Kutuzov, S., and Cogley, J. G.: Global glacier mass changes and their contributions to sea-level rise from 1961 to 2016, Nature, 568, 382-386, https://doi.org/10.1038/s41586-019-1071-0, 2019. 